Spring 1999

\title{
The General Allotment Act "Eligibility" Hoax: Distortions of Law, Policy, and History in Derogation of Indian Tribes
}

John P. LaVelle

University of New Mexico - School of Law

Follow this and additional works at: https://digitalrepository.unm.edu/law_facultyscholarship

Part of the Indian and Aboriginal Law Commons

\section{Recommended Citation}

John P. LaVelle, The General Allotment Act "Eligibility" Hoax: Distortions of Law, Policy, and History in Derogation of Indian Tribes, 14 Wicazo Sa Review 251 (1999).

Available at: https://digitalrepository.unm.edu/law_facultyscholarship/575

This Article is brought to you for free and open access by the UNM School of Law at UNM Digital Repository. It has been accepted for inclusion in Faculty Scholarship by an authorized administrator of UNM Digital Repository. For more information, please contact amywinter@unm.edu, Isloane@salud.unm.edu, sarahrk@unm.edu.

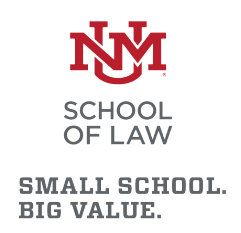

BIG VALUE. 


\section{The General Allotment Act "Eligibility" Hoax Distortions of Law, Policy, and History in Derogation of Indian Tribes}

Jobn P. LaVelle

In 1992, South End Press of Boston published a collection of essays titled The State of Native America, edited by M. Annette Jaimes. The centerpiece of this scholarly appearing volume is a brief essay titied "Federal Indian Identification Policy: A Usurpation of Indigenous Sovereignty in Native North America," 1 a controversial polemic by Jaimes. My primary focus in this critique is the veracity of some remarkable assertions bearing on the field of Indian law and the sovereign rights of Indian tribes as put forth in Jaimes's essay. These assertions have been relied on by other authors since publication of The State of Native America ${ }^{2}$ and have been embraced with particular enthusiasm by writer Ward Churchill, the author of numerous highly controversial commentaries on federal law and Indian tribes. Before scrutinizing Jaimes's dubious assertions, a few observations concerning Churchill's relationship with her essay are in order.

At the time The State of Native America was published, M. Annette Jaimes-known today as Marianette Jaimes-Guerrero (an incorporation of a former pseudonym, "Marianna Guerrero") ${ }^{3}$ - was a colleague of Churchill's at the Center for Studies of Ethnicity and Race in America (CSERA) at the University of Colorado at Boulder. In The State of Native America, Churchill formally is acknowledged as the author or coauthor of four essays in the volume ${ }_{i}{ }^{4}$ moreover, Churchill's distinctive antitribal ideology 5 permeates many of the essays in the volume, even those purportedly authored by others, such as "Federal Indian Identification 
Policy" and "American Indian Water Rights," the latter attributed to Marianna Guerrero. ${ }^{6}$ Indeed, so interchangeable are the ideology, rhetoric, and writing style in "Federal Indian Identification Policy," the essay by Marianna Guerrero, and other essays in the volume with essays that have appeared under Churchill's name in books such as Struggle for the Land and Indians Are $U_{5}{ }^{7}$ that whole passages from essays in The State of Native America by authors other than Churchill can be found in near-verbatim form in Churchill's other writings. ${ }^{8}$ Thus, read. ers should note from the outset that it remains unclear whether the controversial assertions in "Federal Indian Identification Policy" in fact originated with Jaimes-Guerrero alone or instead were the product of an unspoken collaboration between CSERA colleagues Jaimes-Guerrero and Churchill. That Churchill may have had a hand in drafting "Federal Indian Identification Policy" would help explain the zeal with which he continues to embrace and propagate the controversial assertions that originated therein and that, as discussed below, are false.

\section{THE STATE OF NATIVE AMERICA: ORIGINS OF THE GENERALALLOTMENT A CT "ELIGIBILITY" HOAX}

The Jaimes-Guerrero/Churchill thesis as first expressed in "Federal Indian Identification Policy" is that Indian tribes deserve to be reviled and actively opposed for employing tribal membership criteria that require an individual to be possessed of a given degree or "quantum" of tribe-specific Indian blood-typically one-fourth-in order to be eligible for tribal enrollment. According to that thesis, tribes' "blood quantum" requirements are odious and objectionable because these requirements originated in the General Allotment Act of 1887 (also called the Dawes Act), ${ }^{9}$ an act of Congress that ushered in the socalled allotment and assimilation era of federal Indian policy. The act had a devastating impact on Indian tribes, resulting in a loss of twothirds of all Indian land holdings-ninety million acres-by the time the allotment process was brought to a halt by congressional passage of the Indian Reorganization Act in $1934 . .^{10}$ In the words of JaimesGuerrero, the General Allotment Act entailed "a devious approach" to manifesting the federal government's desire to avoid discharging its treaty obligations to Indian tribes:

This [devious approach] was found in the so-called "blood quantum" or "degree of Indian blood" standard of American Indian identification which had been adopted by Congress in 1887 as part of the General Allotment Act. The function of this piece of legislation was to expedite the process of Indian "civilization" by unilaterally dissolv- 
ing their collectively (i.e., nationally) held reservation land holdings. Reservation lands were reallocated in accordance with the "superior" (i.e., Euroamerican) concept of property: individually deeded land parcels, usually of 160 acres each. Each Indian, identified as being those documentably of one-balf or more Indian blood, was entitled to receive title in fee of such a parcel; all others were simply disenfranchised altogether. Reserved Indian land which remained unallotted after all "blooded" Indians had received their individual parcels was to be declared "surplus" and opened up for non-Indian use and occupancy.

Needless to say, there was nowhere near enough Indians meeting the Act's genetic requirements to absorb by individual parcel the quantity of acreage involved in the former reserved land areas. ...

By the early 1900s, then, the eugenics mechanism of the blood quantum had already proven itself such a boon in the federal management of its Indian affairs that it was generally adapted as the "eligibility factor," triggering entitlement to any federal service from the issuance of commodity rations to health care, annuity payments, and educational benefits. If the government could not repeal its obligations to Indians, it could at least act to limit their number, thereby diminishing the cost associated with underwriting their entitlements on a per capita basis. Concomitantly, it must have seemed logical that if the overall number of Indians could be kept small, the administrative expenses involved in their service programs might also be held to a minimum. Much of the original impetus toward the federal preemption of the sovereign Indian prerogative of defining "who's Indian," and the standardization of the racist degree-of-blood method of Indian identification, derived from the budgetary considerations of a federal government anxious to avoid paying its bills. ${ }^{11}$

Having thus established in her readers' minds the perception that the General Allotment Act restricted eligibility for allotments exclusively to Indians who were "documentably of one-balf or more Indian blood," Jaimes-Guerrero criticizes Indian tribes for purportedly having modeled their tribal enrollment requirements on this federally imposed standard:

What has occurred is that the limitation of federal resources allocated to meeting U.S. obligations to American Indians has become so severe that Indians themselves have 
increasingly begun to enforce the race codes excluding the genetically marginalized from both identification as Indian citizens and consequent entitlements. In theory, such a posture leaves greater per capita shares for all remaining "bona fide" Indians. ${ }^{12}$

Jaimes-Guerrero concludes that unless Indian people rise up and forcefully throw off Indian tribes' own "racist" enrollment requirements as derived from the despised General Allotment Act's "blood quantum mechanism," a grim future lurks on the horizon for all Indian people:

If American Indians are able to continue the positive trend in which we reassert our sovereign prerogative to control the criteria of our own membership, we may reasonably assume that we will be able to move onward, into a true process of decolonization and reestablishment of ourselves as functioning national entities. The alternative, of course, is that we will fail, continue to be duped into bickering over the question of "who's Indian" in light of federal guidelines, and thus facilitate not only our own continued subordination, expropriation, and colonization, but ultimately our own statistical extermination. ${ }^{13}$

A major defect in Jaimes-Guerrero's (and, as discussed below, Churchill's) attack on Indian tribes' use of blood quantum requirements in tribes' enrollment criteria is that this assault rests squarely on a foundation of false information about the General Allotment Act. Despite Jaimes-Guerrero's and Churchill's repeated assertions that the act required any Indian applying for an allotment to be "one-half or more Indian blood" in order to receive an allotment, the General Allotment Act in fact contains no sucb requirement. Rather, Jaimes-Guerrero and Churchill apparently have fabricated this "requirement" in order to foment, through the presentation of false and misleading information, popular hostility toward Indian tribes.

THE GENERALALLOTMENT ACT: WHAT IT SAYS, AND WHAT IT DOESN'T SAY

The General Allotment Act is codified, as amended, in Title 25 of United States Code Annotated (U.S.C.A.). ${ }^{14}$ The act's various components are interspersed among other topically related congressional enactments that, taken all together, make up Chapter 9 (Allotment of Indian Lands) and Chapter 11 (Irrigation of Allotted Lands) of U.S.C.A. Title 25. Chapter 9 alone-which covers the bulk of the codified provisions of the General Allotment Act (all but sec. 381)-spans 211 pages of text, ref- 
erences, and notes ${ }_{i}$ Chapter 11 -which contains the single codified provision of the General Allotment Act pertaining to the irrigation of allotted lands (sec. 381) - spans an additional 16 pages of text, references, and notes. Because of the General Allotment Act's complexity and its distribution in Title 25 of U.S.C.A. among a number of references to other congressional enactments-some of which do, in fact, make reference to quanta of Indian blood, as discussed below-many readers simply may have taken for granted the validity of Jaimes-Guerrero's and Churchill's recurring assertions about the act's requiring Indians to be "one-half or more Indian blood" in order to receive allotments.

Unfortunately, reliance on the veracity of Jaimes-Guerrero's and Churchill's assertions about the General Allotment Act is grievously misplaced because the act does not contain the federally imposed, blood quantum-centered "eligibility" requirement that those writers repeatedly claim it does. In substance, the codified provisions of the act, as amended, may be summarized briefly as follows: ${ }^{15}$

Sec. 331 authorizes the president to survey Indian lands for the purpose of assigning individual allotments of no more than 80 acres of agricultural land or 160 acres of grazing land " $[\mathrm{i}] \mathrm{n}$ all cases where any tribe or band of Indians has been or shall be located upon any reservation. ..." ${ }^{\prime 16}$

Sec. 332 provides that allotments "shall be selected by the Indians, heads of families selecting for their minor children," but that "agents shall select for each orphan child" as well as for "any one entitled to an allotment [who] fail[s] to make a selection within four years after the President shall direct that allotments may be made on a particular reservation."

Sec. 333 authorizes "special allotting agents" appointed by the president to assign individual allotments to reservation Indians.

Sec. 334 provides that an allotment from public domain lands shall be available for "any Indian not residing upon a reservation, or for whose tribe no reservation has been provided."

Sec. 339 exempts the lands of certain tribes, including seven tribes located in Oklahoma, from the act's applicability.

Sec. 341 specifies that the act does not affect "the right and power of Congress to grant the rights of way through any lands granted to an Indian, or a tribe of Indians, for railroads or other highways, or telegraph lines, for the public use, or to condemn such lands to public uses, upon making just compensation." 
Sec. 342 specifies that the act does not "prevent the removal of the Southern Ute Indians from their present reservation in southwestern Colorado to a new reservation by and with the consent of the adult male members of said tribe." Sec. 348 directs the secretary of the interior to issue "trust patents" to allottees, ensuring that the United States "will hold the land thus allotted, for the period of twenty-five years, in trust for the sole use and benefit of the Indian [allottee]," after which period "fee patents" would be issued, "discharged of said trust and free of all charge or incumbrance whatsoever." This section also authorizes the secretary of the interior to negotiate, under the president's direction, with any tribe whose lands have been allotted "for the purchase and release by said tribe ... of such portions of its reservation not allotted as such tribe shall, from time to time, consent to sell," and authorizes homesteading by white settlers on any such ceded "surplus lands." Further, this section permits religious societies and other organizations to continue occupying reservation lands they occupied at the time the act was passed "for religious or educational work among the Indians," and it specifies a preference for the hiring of Indians in public service positions related to the act's implementation, so long as such Indians "have availed themselves of the provisions of this Act and become citizens of the United States."

Sec. 349 provides that Indian allottees would become subject to state civil and criminal laws, and, originally, that they would become citizens of the United States and of the respective states. In 1906, Congress substantially amended this section by passing the "Burke Act," specifying that an allottee would be subject to state laws and rendered a state and federal citizen only after issuance of the final "fee patent" but also providing a mechanism for expediting expiration of the trust status of allotments by authorizing the secretary of the interior to declare any Indian allottee "competent and capable of managing his or her affairs at any time [and] to cause to be issued to such allottee a patent in fee simple, and thereafter all restrictions as to sale, incumbrance, or taxation of said land shall be removed." ${ }^{17}$ With Congress's passage of the Indian Citizenship Act in 1924, ${ }^{18}$ the provisions of this section of the General Allotment Act relating to the ultimate granting of state and federal citizenship to allottees thereby were mooted, and hence those provisions were omitted from the codification of the act. ${ }^{19}$ 
Sec. 354 provides that an allotment shall not "become liable to the satisfaction of any debt contracted prior to the issuing of the final [fee] patent."

Sec. 381 authorizes the secretary of the interior to regulate the distribution of water necessary to irrigate for agricultural purposes the lands subject to the act in order "to secure a just and equal distribution" of such water among reservation Indians.

In none of these provisions does the General Allotment Act purport to define "Indians" as rendered subject to the act. And certainly there is no language in any of these provisions to suggest that persons of less than half Indian blood were to be considered ipso facto ineligible for allotments, as claimed by Jaimes-Guerrero and Churchill.

However, the Code of Federal Regulations provides clarification regarding Congress's intent in making "Indians" eligible for allotments under the General Allotment Act. The topic of "Indian Allotments" is covered in volume 43 of the Code of Federal Regulations at part 2530; one provision in that part, titled "Qualifications of applicants," reads as follows:

An applicant for allotment under the fourth section ${ }^{20}$ of the [General Allotment Act], as amended, is required to show that he is a recognized member of an Indian tribe or is entitled to be so recognized. Such qualifications may be shown by the laws and usages of the tribe. The mere fact, however, that an Indian is a descendant of one whose name was at one time borne upon the rolls and who was recognized as a member of the tribe does not of itself make such Indian a member of the tribe. The possession of Indian blood, not accompanied by tribal affiliation or relationship, does not entitle a person to an allotment on the public domain. Tribal membership, even though once existing and recognized, may be abandoned in respect to the benefits of the fourth section. ${ }^{21}$

As indicated in this provision from the Code of Federal Regulations, Congress did not make eligibility for allotments under the General Allotment Act hinge upon an applicant being "documentably of one-half or more Indian blood," as Jaimes-Guerrero erroneously asserts in "Federal Indian Identification Policy." Indeed, in enacting the 1887 General Allotment Act, Congress imposed no blood quantum-specific "eligibility" requirement on Indians at all. Instead, Congress made eligibility for allotments under the act depend exclusively on the tribes' own independent membership determinations. And as the substantive regulation 
interpreting the statute expressly states, whether an applicant qualifies for an allotment by virtue of being a tribal member is a question to be resolved according to the tribe's own sovereign criteria and tradi. tions: "Such qualifications may be shown by the laws and usages of the tribe."22

That Congress did not limit eligibility for allotments under the General Allotment Act to persons "of one-half or more Indian blood" is further evinced by congressional passage of legislation in 1894, 1901, and 1911, together providing, as codified at 25 U.S.C.A. sec. 345 under the heading "Actions for allotments," that "[a]ll persons who are in whole or in part of Indian blood or descent who are entitled to an allot. ment of land under any law of Congress, or who claim to be so entitled to land under any allotment Act" are permitted to bring suit in federal court to vindicate their asserted rights. ${ }^{23}$ It would seem strange indeed if Congress in the years immediately following passage of the General Allotment Act had created a right of action for individuals of any degree of Indian lineage to secure their allotment rights if the General Allotment Act itself had denied allotments to all Indians except those "of one-half or more Indian blood." While the implementation of Congress's allotment policy assuredly was misguided-catastropbically soit did not reach the degree of absurdity that would obtain if JaimesGuerrero's version of historical events were to be believed since in truth the General Allotment Act did not limit eligibility for allotments in the manner described by Jaimes-Guerrero.

An entry in the legal encyclopedia American Jurisprudence also reflects the fact that the General Allotment Act contains no requirement that an Indian applying for an allotment under the act be "of one-half or more Indian blood" but instead renders eligible for an allotment any member of an Indian tribe, regardless of degree of Indian blood. Under the heading "Persons Entitled to Allotment," American Jurisprudence summarizes the law in the following terms:
The provision of the General Allotment Act, governing allotments to Indians on reservations, makes no distinc- tion between Indians of full and mixed blood ${ }_{i}$ rather, all Indians, whether of full or mixed blood, who are living on a reservation in the tribal relation are entitled to share in the allotment. ${ }^{24}$

Whatever responsible primary or secondary source of information about eligibility for allotments under the General Allotment Act one consults, one finds no reference at all to any "race codes excluding the genetically marginalized from . . identification as Indian citizens." ${ }^{25}$ The reason for this universal absence of any mention of such "race codes" is that the General Allotment Act contains no such "race codes" 
for determining eligibility for allotments. For although the General Allotment Act without a doubt represented a contemptible effort by Congress-motivated by prevailing prejudices that viewed Indian people as racially and culturally inferior-to strip Indian tribes of all collectively held lands, force Indian people to assimilate into white society, and generally undermine the tribes' territorial sovereignty ${ }^{26}$ the 1887 legislation nevertheless did not effectuate a "usurpation" of the sovereign right of tribes to determine their own members, as JaimesGuerrero claims. Then, as now, it was the tribes themselves-not the federal government-which maintained and guarded the sovereign prerogative of determining tribal citizenship. ${ }^{27}$

To be sure, after Congress amended the General Allotment Act by passing the so-called Burke Act in 1906, ${ }^{28}$ federal officials entrusted with administering the allotment program did employ from 1917 to 1920 a scheme whereby determinations as to whether allottees were "competent and capable of managing [their] affairs"-and hence subject to having the trust status of their allotments canceled by the issuance of "fee patents" - -were linked to allottees' percentage of Indian blood. This allotment policy implementation scheme was announced on April 17, 1917, by Indian Affairs Commissioner Cato Sells, and as historian Janet McDonnell has noted, it "arbitrarily release[d] thousands of Indians from guardianship and contribute[d] greatly to the destruction of the Indian estate." McDonnell elaborates:

After $1917, \ldots$ the government had the authority to force fee patents on Indians in two ways: on the basis of a competency commission recommendation, or by arbitrary issuance to an allottee with less than one-half Indian blood who was able-bodied and mentally competent. The 1906 Burke Act had given the Indian Office the authority to issue fee patents before the end of the trust period only when Indian landholders applied for them. Sells and [Secretary of the Interior Daniel K.] Lane, however, misconstrued the Burke Act. Without any legislative authority, in 1917 they began forcing fee patents on all Indians with a certain blood quantum whether they wanted them or not. ${ }^{29}$

With growing concerns about the tragic social effects-especially the swelling tide of Indian poverty and homelessness-that resulted from the government's experimental use of blood quantum to determine "competency," and with President Woodrow Wilson's appointment of John Barton Payne to replace Lane as secretary of the interior, the Indian Office effectively abandoned that controversial policy in 1920, resuming a more conservative, case-by-case approach to determinations of "competency. ${ }^{\text {" }} 0$ In an overall assessment of the Indian Office's "competency" 
policy as implemented during the years 1917-20, McDonnell writes: "The policy of arbitrarily issuing fee patents to certain Indians without their consent was immoral and illegal. It violated both the provisions and the intent of the Dawes Act. Moreover, that policy was racist in that it directly linked percentage of white blood to competency."

Of course, the Wilson administration's 1917-20 "competency" policy assuredly is not what Jaimes-Guerrero purports to be describing when she asserts that under the 1887 General Allotment Act, "[e]ach Indian, identified as being those documentably of one-balf or more Indian blood, was entitled to receive title in fee of such a parcel; all others were simply disenfranchised altogether." ${ }^{32}$ Still, it is possible that JaimesGuerrero is somehow confusing "eligibility" for an initial allotment under the 1887 legislation with "eligibility" for unilateral cancellation of an allotment's trust status under the 1917-20 "competency" policy. But since Jaimes-Guerrero provides no citations at all to any authority supporting her erroneous statements concerning the federal government's allotment policy, the explanation for her confusion remains a mystery. And in any event, Jaimes-Guerrero's eagerness to "beat up the victim" of allotment policy-that is, Indian tribes themselves-by falsely accusing tribes of complicity in that destructive and insidious policy ${ }^{33}$ surely betrays a more pervasive deficiency in Jaimes-Guerrero's approach to Indian law and policy than merely a tendency to confuse and misreport historical facts.

To more clearly comprehend the illegitimacy of the aspersions that Jaimes-Guerrero casts on Indian tribes via the General Allotment Act's purported "'degree of Indian blood' standard of American Indian identification," an additional complexity concerning turn-of-thecentury allotment policy must be addressed. One must take care to distinguish the General Allotment Act itself-codified as amended in the precise sequence of U.S.C.A. sections listed and summarized earlierfrom other, subsequent federal legislation pertaining to specific named tribes and mentioned intermittently among the U.S.C.A. notes and references that accompany the act's codified provisions. In some instances Congress imposed blood quantum restrictions with respect to the inheritance of Indian lands allotted to the members of particular tribes under acts other than the General Allotment Act, and as alluded to previously, in the corresponding annotations reflecting the language used by Congress and by interpreting courts for describing and discussing those restrictions, phrases like Jaimes-Guerrero's "one-half or more Indian blood" occur periodically. ${ }^{34}$

But these assorted annotations employing the phrase "one-half or more Indian blood" and similar phrases in U.S.C.A. emphatically do not pertain to eligibility for allotments under the General Allotment Act, the subject of Jaimes-Guerrero's and Churchill's recurring distor- 
tions. Rather, such phrases in the U.S.C.A. annotations appear only in connection with special acts of Congress addressing the supervision of the lands of those few tribes expressly exempted from the application of the General Allotment Act. ${ }^{35}$ Thus, the presence of the phrase "onehalf or more Indian blood" within some of those annotations in no way lends credence to Jaimes-Guerrero's and Churchill's assertions about who Congress understood "Indians" to be when Congress passed the General Allotment Act. As must be repeated, Congress did not limit eligibility for allotments under the General Allotment Act to persons "of one-half or more Indian blood." Rather, Jaimes-Guerrero and Churchill have invented that nonexistent "standard" in order to denigrate the sovereign enrollment criteria of Indian tribes.

Thus, despite praise elsewhere in The State of Native America of Jaimes-Guerrero for having done "a fine job of exposing the political and economic ramifications of the U.S. imposition of eugenics codes upon Native Americans," ${ }^{36}$ it is clear that in "Federal Indian Identification Policy" she in fact has built her anti-tribal thesis on a foundation of false assertions about the contents and meaning of the General Allotment Act. Once again, it is important to note carefully that with respect to the dramatic assertions contained in the lengthy passages quoted earlier from "Federal Indian Identification Policy," JaimesGuerrero provides no citation to any section of the General Allotment Act wherein her "half-blood or more" eligibility "standard" can be found. The reason for this omission is clear: the General Allotment Act does not contain the eligibility "standard" that Jaimes-Guerrero falsely has assigned to it. That Jaimes-Guerrero has done "a fine job" of disparaging Indian tribes with this invented information is, at best, an indication of that writer's effectiveness as a conduit for the spreading of false propaganda in derogation of tribal sovereignty.

However, it is Churchill who has gotten the most mileage from the false information contained in "Federal Indian Identification Policy." Beginning with a "table" in The State of Native America coauthored with Glenn T. Morris and titled "Key Indian Laws and Cases," Churchill on numerous occasions has repeated the false General Allotment Act "eligibility" scheme in his continuing efforts to facilitate through his writings the proliferation of negative public attitudes toward Indian tribes. Thus, Churchill and Morris include the following description in summarizing the General Allotment Act:

In order to retain any land at all, native people-legally defined for the first time on the basis of a racist "blood quantum" code employed for identification purposes by the federal government-were compelled to accept individually deeded land parcels. ${ }^{37}$ 
Like Jaimes-Guerrero, Churchill and Morris provide no citation to
any particular provision of the General Allotment Act that would en. able a reader to ascertain the validity of their allegations about the ex. istence of a "racist 'blood quantum' code" that the federal government allegedly contrived and employed in deciding whether Indian appli. cants for allotments were eligible to receive "any land at all" under the act's provisions. This lack of a supporting citation is explained by the fact that, contrary to Churchill and Morris's assertions, the General Allotment Act never contained any such federally imposed eligibility "code" at all. ${ }^{38}$

\section{STRUGGLEFOR THE LAND: TAKING THE HOAX AND RUNNING WITH IT}

In his book Struggle for the Land, published in 1993, Churchill again propagates his General Allotment Act "eligibility" scheme in passages animated by increasingly strident denunciations of Indian tribes-and, once again, without ever providing a verifiable citation to the General Allotment Act. In an essay in Struggle for the Land titled "Perversions of Justice," Churchill states that the General Allotment Act "imposed for the first time a formal eugenics code-dubbed blood quantum-by which American Indian identity would be federally defined on racial grounds rather than by native nations themselves on the basis of group membership/citizenship. ${ }^{\prime \prime 9}$ Churchill appends an endnote to this passage that cites not the General Allotment Act but rather solely JaimesGuerrero's "Federal Indian Identification Policy" in its entirety. ${ }^{40}$ Within that endnote, Churchill includes the following comment: "It is noteworthy that official eugenics codes have been employed by very few states, mostly such unsavory examples like nazi Germany (against the Jews), South Africa (against 'Coloreds') and Israel (against Palestinian Arabs)." ${ }^{41}$

Churchill's attempt to denigrate Indian tribes' enrollment procedures by associating those procedures with the "federal eugenics criteria" 42 allegedly contained in the General Allotment Act and with the "unsavory" practices of oppressive regimes like Nazi Germany and apartheid-embracing South Africa is unavailing, however, because of Churchill's failure to establish even the existence of the "federal eugenics criteria" that, in Churchill's scheme, was grafted onto Indian tribes' enroilment procedures by the General Allotment Act. Moreover, Churchill is incapable of overcoming this fatal flaw in his anti-tribal scheme by relying exclusively on Jaimes-Guerrero's "Federal Indian Identification Policy" because, as explained earlier, Jaimes-Guerrero, too, had built her General Allotment Act "eligibility" scheme on fabricated assertions that she, like Churchill, did not even attempt to trace directly to the General Allotment Act itself. ${ }^{43}$ 
Churchill carries forward his propaganda-driven attack on tribal self-determination in another essay in Struggle for the Land, titled "American Indian Self-Governance." Here, Churchill gives expression to his anti-tribal sentiments by impugning the government of the Navajo Nation. In one segment of that diatribe, Churchill asserts the following:

Even the citizenry of the Navajo Nation has been defined by the federal government through imposition of a formal eugenics code termed "blood quantum" and nearly a century of direct control over tribal rolls described elsewhere in this volume. These methods of manipulating and arithmetically constricting the indigenous population have become so imbedded in the Indian consciousness and psyche that Washington can rely upon the "self-governance" mechanisms of Native America to abandon their own traditions and concern with sovereignty, adhering to federal definitions of Indian identity. The ugly burden of imposing racism is now carried out by the oppressed themselves. ${ }^{44}$

Churchill's reference to matters "described elsewhere in this volume" that presumably explain the federal government's "direct control over tribal rolls" is an allusion to Churchill's prior, unsubstantiated assertions in "Perversions of Justice," discussed earlier, concerning the General Allotment Act's alleged "federal eugenics criteria." As in that previous essay, Churchill in "American Indian Self-Governance" provides no citation to the General Allotment Act to support his allegations in derogation of Indian tribes. Instead, in an endnote Churchill advises readers to consult a version of Jaimes-Guerrero's "Federal Indian Identification Policy" "[f]or detailed elaboration on this theme." 45

Churchill again invokes this "theme" in the final essay in Struggle for the Land, a piece titled "I Am Indigenist." At the beginning of that essay, Churchill professes himself to be "one who not only takes the rights of indigenous peoples as the highest priority of my political life, but who draws upon the traditions-the bodies of knowledge and corresponding codes of values-evolved over many thousands of years by native peoples the world over. ${ }^{\prime 46}$ Notwithstanding this attempt to portray himself as a champion of Indian rights, Churchill uses the occasion of his "I Am Indigenist" manifesto to further his attack on tribal self-determination and tribal sovereignty, aggressively putting forth once again his false General Allotment Act "eligibility" scheme in order to disparage Indian tribes. He writes:

The Europeans and subsequent Euroamerican settlers... foisted the notion that Indian identity should be determined 
primarily by "blood quantum" an outright eugenics code similar to those developed in places like nazi Germany and apartheid South Africa. Now, that's a racist set of policies and principles if there ever was one. Unfortunately, a lot of Indians have been conned into accepting this anti-Indian absurdity, and that's something to be overcome. But there's also solid indication that quite a number of native people continue to strongly resist such things as the quantum system. $^{47}$

Churchill appends an endnote to this propaganda, advising readers to "see" Jaimes-Guerrero's essay in The State of Native America for additional information "[o]n federal quantum policy." And, as always, Churchill neglects to provide any citation to the General Allotment Act itself. 48

\section{INDIA NS AREUS?}

\section{REPEATING THE HOAXANDALLOTTING IT IN SEVERALTY TO OTHERS}

In his next book, Indians Are Us?, Churchill invokes the false General Allotment Act "eligibility" scheme in three different essays. First, in "Bringing the Law Home," Churchill alerts his readers to "such seemingly innocuous federal policies as those concerning Indian identification criteria," which, according to Churchill, "carry with them an evident genocidal potential." Churchill then averts once again to "a eugenics formulation—dubbed 'blood quantum' - ushered in by the 1887 General Allotment Act," by means of which "the government has set the stage for a 'statistical extermination' of the indigenous population within its borders. ${ }^{\prime \prime 9}$ In an endnote, Churchill asserts-again, without citing any supporting authority for the "standard" that he encloses in quotations marks-that "[t]he 1887 'standard' was 'one-half or more degree of Indian blood.'" At the conclusion of that same endnote, Churchill elaborates only that "[ $t]$ he term 'statistical extermination' comes from M. Annette Jaimes, 'Federal Indian Identification Policy,' The State of Native America..$^{50}$ In thus making an unsubstantiated statement about the General Allotment Act and its effect on Indian tribes, accompanied by a reference to similarly unsubstantiated assertions in JaimesGuerrero's "Federal Indian Identification Policy," Churchill propagates his anti-tribal thesis by means of a familiar formula.

But Churchill then takes a new tack by invoking a passage from a different writer, the acclaimed historian Patricia Nelson Limerick. ${ }^{51}$ In the midst of his dubious statements about the "genocidal potential" of the General Allotment Act's "Indian identification criteria," Churchill cites to Limerick's book The Legacy of Conquest ${ }^{52}$ to suggest that Limerick shares his own concerns about Indian tribes' purported de facto adop- 
tion of the General Allotment Act's "eligibility", standard in tribes' enrollment criteria. Churchill writes:

As the noted western historian, Patricia Nelson Limerick, has observed: "Set the blood-quantum at one-quarter, hold to it as a rigid definition of Indians ["Indianness" in Limerick's original], let intermarriage proceed ... and eventually Indians will be defined out of existence. When that happens, the federal government will finally be freed from ["free of" in Limerick's original] its persistent 'Indian problem'. "Ultimately, there is precious little difference, other than matters of style, between this and what was once called the "Final Solution of the Jewish Problem."

But in the passage that Churchill extracts from The Legacy of Conquest, Limerick in fact is not referring to the General Allotment Act at all, Churchill's insinuation to the contrary notwithstanding. Instead, Limerick is emphasizing the validity of Indian tribes' strong (and ultimately successful) objections to the Reagan administration's efforts in 1986 to limit unilaterally the number of Indian people eligible for health care administered by Indian Health Service by requiring any applicant for benefits to have in addition to tribal membership status "at least one-quarter Indian blood."54 Indeed, far from opposing tribes' own enrollment prerogatives, Limerick implicitly endorses the right of Indian tribes to determine their own members as an indispensable attribute of tribal sovereignty. The fact that Churchill finds it necessary to contrive a false facade of scholarly support for his anti-tribal thesis by misrepresenting the observations of Limerick ultimately serves only to underscore the true lack of any such support from within the ranks of legitimate scholars.

The next articulation in Indians Are Us? of the Jaimes-Guerrero/ Churchill General Allotment Act "eligibility" scheme arises in Churchill's essay "Nobody's Pet Poodle." Under the heading "Arithmetical Genocide," Churchill executes an invective against the Indian Arts and Crafts Act, a statute enacted by Congress in 1990 in response to concerns raised by tribal leaders and Indian rights advocates about non-Indians falsely representing their artwork as Indian-made in the lucrative art markets of the American Southwest and elsewhere. ${ }^{55}$ Endeavoring to discredit Congress's deference in the Indian Arts and Crafts Act to

membership rolls originated in the prevailing federal racial criteria of the late 19 th century. The initial U.S. motive in quantifying the number of Indians by blood was to 
minimize the number of land parcels it would have to as. sign native people under provision of the 1887 Dawes Act, thereby freeing up about two-thirds of all reservation land for "homesteading" by non-Indians or conversion into U.S. park and forest land. Tribal rolls have typically been maintained in this reductionist fashion ever since . . 56

Once again, Churchill provides no citation to the General Allotment Act. He does indicate his reliance, however, on Jaimes-Guerrero's "Federal Indian Identification Policy," and he repeats his own prior mis. representation of the views of Limerick:57

Obviously involved is what the Juaneño/Yaqui scholar M. Annette Jaimes calls "a sort of statistical extermination" whereby the government seeks not only to keep costs associated with its discharge of Indian Affairs at the lowest possible level, but to eventually resolve its "Indian prob. lem" altogether. The thinking is simple. As the historian Patricia Nelson Limerick frames it: "Set the blood quantum at one-quarter, hold to it as a rigid definition of Indians ["Indianness" in Limerick's original], let intermarriage proceed as it has ["had" in Limerick's original] for centuries, and eventually Indians will be defined out of existence." ${ }^{58}$

In this manner, Churchill continues to reinforce the edifice of propaganda whose foundation he and Jaimes-Guerrero first had established in The State of Native America, purporting to find "support" for this effort in the work of a renowned scholar, Limerick.

But Churchill then takes this disinformation campaign one step farther by supplementing his distortion of Limerick's views with a similar misrepresentation of the views of Russell Thornton, author of the important study of the history of the native population of the Americas, American Indian Holocaust and Survival. ${ }^{59}$ Churchill attributes to Thornton a concern about the "disappear[ance]" of "Native America as a whole ... by the year $2080^{\prime \prime}$ if the "imposition of purely racial definitions" continues. ${ }^{60}$ To this purported reliance on the views of Thornton, Churchill appends an endnote directing readers to pages 174-82 of Thornton's American Indian Holocaust and Survival. ${ }^{1}$

But in fact, Thornton makes no such prediction about the demise of Indians in the twenty-first century-not within the range of pages cited by Churchill nor anywhere else in Thornton's book. Indeed, Thornton's outlook concerning the future population of American Indian people is notably optimistic-quite opposite the view that Churchill has assigned him. ${ }^{62}$ Thus, once again Churchill's asserted reliance on an acclaimed scholar, Thornton, for the decidedly anti-tribal 
propositions put forth by Churchill does not withstand even a cursory inquiry into the validity of that reliance. Instead, when one investigates Churchill's purported presentation of the views of Thornton, one finds that Churchill grossly misstates those views, just as he does with regard to the views of Limerick. Notwithstanding Churchill's misrepresentations, neither Thornton's work nor Limerick's endorses or condones opposition to Indian tribes' enrollment requirements. And certainly neither of these prominent scholars can be said to embrace, by any stretch, the general hostility toward Indian tribes that pervades and distinguishes Churchill's writings.

Churchill again interjects his fabricated General Allotment Act "eligibility" scheme in the final essay in Indians Are Us? titled "Naming Our Destiny." Here, Churchill delivers a prolonged harangue against popular use of the word tribe, ${ }^{63}$ positing that "to be addressed as 'tribal' is to be demeaned in an extraordinarily vicious way." 64 Opining further that use of the word tribe represents complicity in "a resoundingly racist construction," Churchill writes:

Undoubtedly, there are those ... who will wish to argue that such an assessment is overly harsh, that it is somehow skewed toward the negative. Use of the term [tribe] with regard to American Indians in this day and age, they will contend, is actually a positive gesture affording appropriately respectful homage to the uniqueness of Native American traditions, especially the importance of kinship systems in indigenous societies. Despite the surface plausibility of such assertions, they are ultimately vacuous, overlooking as they do the operant realities of traditional native life. While it is true that most indigenous societies were, and in many cases are, organized along lines of kinship, this hardly implies the preoccupation with "blood" lines connoted by the term "tribe." 65

To this, Churchill appends an endnote with familiar content:

The preoccupation is actually a matter of U.S. policy implementation; a system of identifying Indians in accordance with a formal eugenics code dubbed "blood quantum" which is still in effect at the present time. For analysis of the effects of this, see M. Annette Jaimes, "Federal Indian Identification Policy ...," in ... The State of Native America ... ${ }^{66}$

From both the passage from the body of the text and its corresponding endnote, it would appear that Churchill's use of invented historical information concerning the General Allotment Act is part and parcel 
of Churchill's elaboration of additional, related propaganda, such as his

fostering of a condemning public attitude generally toward Indian tribes that formally refer to themselves as such. Hence, readers who do not partake of Churchill's abhorrence for the word tribe should understand that they have no cause for embarrassment or apology, since Churchill's display of contempt here is merely one manifestation of an anti-tribal propaganda campaign that is passionately dedicated to "overlooking" not just "the operant realities of traditional native life," but "the operant realities" of numerous other matters pertaining to history, law, and pol. icy as well.

\section{SINCE PREDATOR CAME AND}

\section{FROM A NATIVE SON: RECLAIMING THE HOAX, EMBELIISHING IT, REPUBLISHING IT}

During the years following publication of Indians Are $U_{s}$ ? Churchill has repeated his false claims about the General Allotment Act and its impact on tribal enrollment procedures in three additional books: Since Predator Came (1995), the anthology From a Native Son (1996), and A Little Matter of Genocide (1997). ${ }^{67}$ In all these books, Churchill couches his invocation of the General Allotment Act "eligibility" scheme in increasingly vitriolic denunciations of Indian tribes while simultaneously obscuring the true origins of this scheme by employing elaborately_and sometimes comically-misinforming reference notes that seem designed to frustrate readers' efforts to check the accuracy of Churchill's claims.

In the essay "Since Predator Came" in the volume of the same title, for example, Churchill alleges the following very specific "facts" about the General Allotment Act:

Under provision of this statute, effected in 1887 , a formal eugenics code was utilized to define who was (and who was not) "Indian" by U.S. "standards." Those who could, and ${ }^{68}$ were willing to, prove to federal satisfaction that they were "of one-half or more degree of Indian blood," and to accept U.S. citizenship into the bargain, received a deed to an individual land parcel, typically of 160 acres or less. Once each person with sufficient "blood quantum" had received his or her allotment of land, the remaining reservation land was declared "surplus" and opened up to non-Indian homesteading, corporate acquisition, or conversion into national parks and forests... The model was later borrowed by the apartheid government of South Africa in developing its "racial homeland" system of territorial apportionment. ${ }^{69}$ 
In support of these assertions Churchill purports to supply several scholarly references-but none of them constitutes verification of the existence of an eligibility "standard" of "one-half or more degree of Indian blood." With respect to his claims about the General Allotment Act's "formal eugenics code," Churchill simply provides no indication of where one might look to verify the existence of this "code." Instead, Churchill writes in an accompanying endnote, "On this aspect, see Ward Churchill, 'Nobody's Pet Poodle,'"70 in Indians Are Us?-but, as discussed earlier, that essay in turn contains only similarly evasive references to the "source" of this asserted blood quantum-specific General Allotment Act "eligibility" scheme. Once again, when the smoke and mirrors are cleared away, it appears that the only known "source" for this scheme is the collective imagination of Churchill and Jaimes-Guerrero.

As for Churchill's statement at the end of this excerpt from the essay "Since Predator Came," that as a "model" the General Allotment Act (as erroneously described by Churchill) "was later borrowed by the apartheid government of South Africa in developing its 'racial homeland' system of territorial apportionment," this, too, is fallacious and misleading. The only reference Churchill offers in support of this statement reads as follows: "On these linkages, see George M. Frederickson, Wbite Supremacy: A Comparative Study in American and Soutb African History . . "71 But Churchill indicates no specific pages from the Frederickson book wherein a reader might locate any discussion of "linkages" between the General Allotment Act's purported "blood quantum" eligibility requirement and South Africa's system of apartheid, instead, Churchill cites the 356-pages-long Frederickson book in its entirety.

However, when one examines Frederickson's book, one discovers that while that volume contains much insight as a comparative study of the historical development of white supremacy and governmental subjugation of nonwhites in the United States and South Africa, ${ }^{72}$ nowhere between the covers of the book does Frederickson suggest any "linkages" involving the General Allotment Act's supposed "blood quantum" eligibility requirement, as Churchill falsely insinuates may be found there. But of course, any discussion by Frederickson of such "linkages" would be quite surprising given the fact that the General Allotment Act eligibility "standard" of "one-half or more degree of Indian blood" — so crucial to the promotion of anti-tribal sentiments in the writings of Churchill and Jaimes-Guerrero-does not exist.

In another essay in Since Predator Came, titled "Like Sand in the Wind," Churchill spreads his General Allotment "eligibility" propaganda once more:

Under provision of the statute, each Indian identified as such by demonstrating "one-half or more degree of Indian 
blood" was to be issued an individual deed to a specific parcel of land....

Generally speaking, those of mixed ancestry whose "blood quantum" fell below the required level were summarily excluded from receiving allotments. In many cases, the requirement was construed by officials as meaning that an applicant's "blood" had to have accrued from a single people; persons whose cumulative blood quantum derived from intermarriage between several native peoples were thus often excluded as well..$^{73}$

While the overall thrust of these false statements is the same as that found in Churchill's previous enunciations of his General Allotment Act "eligibility" scheme, Churchill's boldness here in putting forth specific fabricated "facts" makes this passage something of an innovation in the development of Churchill's propaganda. One would expect to find exact, accurate citations to historical sources to "back up" such precise observations about how federal officials "construed" federal policy ${ }_{i}$ Churchill provides none. Instead, as "support" for his specific (and doubtful) allegations of historical "fact," Churchill once more cites an entire book-Janet McDonnell's The Dispossession of the American Indian ${ }^{74}$ - without pinpointing any particular pages. ${ }^{75}$ By citing McDonnell's book as a whole as the sole reference for his specific allegations, Churchill again frustrates any reader's effort to verify Churchill's purported "facts."

But more importantly, when one examines McDonnell's thoroughgoing analysis of allotment policy, one finds that there is nothing in The Dispossession of the American Indian to "support" Churchill's "facts" concerning the purported eligibility "standard" of the General Allotment Act and how that "standard" allegedly was "construed" by federal officials. ${ }^{76}$ But, of course, since the Jaimes-Guerrero/Churchill "standard" is nonexistent, readers of The Dispossession of the American Indian should not be too disappointed that $\mathrm{McD}$ onnell makes no mention of it. ${ }^{77}$

After the release of Since Predator Came, Churchill produced an anthology of his previously published writings titled From a Native Son. This book consists entirely of assorted "versions" of Churchill's previously published material; thus in reprinting "versions" of "Since Predator Came," "Like Sand in the Wind," "Nobody's Pet Poodle," and "I Am Indigenist," From a Native Son repeats substantially the same false information about the General Allotment Act and its alleged impact on tribal enrollment procedures as that which had been conveyed in earlier "versions" of those essays. In this way, Churchill brings additional readers under the influence of his and Jaimes-Guerrero's peculiar "version" of American history, law, and policy. ${ }^{78}$ 


\section{A LITTLE MATTER OF GENOCIDE: \\ FALSE "FACTS," PHONY "CITATIONS"}

Troubling discussions of the General Allotment Act and Indian tribes likewise may be found in Churchill's recent book A Little Matter of Genocide. ${ }^{79}$ For instance, in endeavoring to draw what otherwise might be instructive comparisons between the Jewish Holocaust and the long history of genocide suffered by Indian tribes indigenous to the Americas ${ }^{80}$ Churchill bungles and effectively discredits his own analysis by repeating the same false propaganda in derogation of Indian tribes that, over time, has emerged as a serious defect warping the entire corpus of Churchill's writings. Thus, readers of A Little Matter of Genocide are confronted with the now familiar distortion in Churchill's long essay "Nits Make Lice'":

Under provision of the [General Allotment] Act, Indians were universally defined on the basis of "blood quantum" - that is, genetic rather than national-political criteria-for the first time under U.S. law. Once each Indian eligible to be considered one under this new definition had been allotted his or her individual 160-acre parcel, the balance of reserved territory was declared "surplus" and opened to corporate use, homesteading by non-Indians, or conversion into national parks, forests, or military reservations. ${ }^{81}$

Churchill accompanies this purported restatement of historical "fact" with a reference note that-as in Since Predator Came-goes beyond merely repeating the fabrication about the General Allotment Act's "blood quantum" eligibility requirement as originally devised in the pages of Jaimes-Guerrero's The State of Native America. ${ }^{82}$ Rather, in A Little Matter of Genocide, Churchill again proceeds to embellisb that fabrication by purporting to provide precise "details" about how the General Allotment Act's supposed eligibility "standard" was given effect. Thus, in his endnote, Churchill states that in implementing the General Allotment Act's "new definition" of Indians as persons who could "document" that they were "of at least one-half [Indian] 'blood,'" the federal government refused to consider any applicant for an allotment to be "legally identified as native" by virtue of simply adding the quanta of Indian blood from multiple tribal lineages, or by virtue of being formally adopted as a member of an Indian tribe by the tribe itself. ${ }^{83}$

But none of these embellishments of the General Allotment Act's alleged "eligibility" requirement bears true witness to historical fact. As discussed earlier, that act did not require any Indian applicant for an 
allotment to be "of at least one-half [Indian] 'blood,'" but instead effec. tively deferred to Indian tribes' own internal membership standards in determining whether an applicant was an "Indian" and thus "eligible" for an allotment. Hence, the General Allotment Act did not "negate[] one of the most important sovereign prerogatives of native peoples" by defining tribes' "own polities" according to "genetic rather than national-political criteria." Churchill's unsupported, contrary assertions in his reference note are simply untrue.

Nevertheless, Churchill repeats these false assertions in a second essay from A Little Matter of Genocide, titled "Cold War Impacts on Native North America." In that essay, Churchill states that in the early twen. tieth century, "the government, having overseen the extermination of the great bulk of all native people within its boundaries, was in the process of formally assimilating (digesting) the residue, both territorially and in terms of population. ${ }^{184}$ In the asterisked footnote ${ }^{85}$ that accompanies this statement, Churchill adds the following:

The primary means by which this was to be accomplished was the 1887 General Allotment Act (ch. 119, 24 Stat. 362,385 , now codified at 18 U.S.C. 331 et seq.). . . Once each Indian-defined on the basis of a restrictive "blood quantum" formula designed to minimize the number of people eligible- - had been allotted his or her individual parcel (averaging 160 acres apiece), the balance of reserved territory was declared "surplus" and opened up to non-Indian usage. ${ }^{86}$

What is most intriguing about this footnote's invocation of the fabricated General Allotment Act "eligibility" scheme is that it repeats verbatim the same counterfeit citations that appear in the endnote, discussed earlier, from Churchill's essay "Nits Make Lice.'" 87 Since these counterfeit citations in fact are not citations to the General Allotment Act in United States Statutes at Large or as codified in United States Code, as Churchill holds them out to be, readers who might have presumed that in A Little Matter of Genocide Churchill at last has provided a verifiable indication of the legal source of his "eligibility" scheme will find themselves sadly mistaken.

So where does Churchill, by way of these "citations," steer readers who want to see evidence of the existence of Churchill's General Allotment Act "eligibility" requirement? Following up on the "leads" provided by Churchill's "citations," one is guided to a part of an "act to grant the Maricopa and Phoenix Railway Company of Arizona the right of way through the Gila River Indian Reservation," 88 to a part of an "act to regulate commerce" setting up administrative and judicial remedies for violations of the act by common carriers, ${ }^{89}$ and to a provi- 
sion from United States Code that specifies penalties for-ironically - the falsification of coins! $!^{90}$

All told, from publication of The State of Native America in 1992 to the release of A Little Matter of Genocide in 1997, Churchill has put forward his false assertions about the General Allotment Act's "eligibility" scheme no fewer than sixteen times in eleven essays published or republished in six different books. ${ }^{91}$ In the course of all these multiple iterations of his tribal enrollment/General Allotment Act conspiracy theory, Churchill never once has provided a verifiable citation to the General Allotment Act itself or to any other legitimate source to prove the existence, as a matter of historical record, of Churchill's "one-half or more degree of Indian blood" requirement for obtaining allotments under that act. Indeed, Churchill is incapable of producing any verifiable historical evidence of the General Allotment Act's purported blood quantum-centered "eligibility" requirement because, in reality, no such requirement ever has existed. Churchill's recurring reference to this nonexistent requirement is merely one ploy in that writer's continuing campaign to create negative public attitudes toward Indian tribes by means of distortion, evasion, and propaganda. ${ }^{92}$

\section{CONTEM PORARY REASSERTION OF THE HOAX: GANGING UP ON THE INDIAN ARTS AND CRAFTSACT}

While the focus of the this essay has been Churchill's and JaimesGuerrero's alterations of fact with respect to a specific piece of federal Indian legislation enacted in the late nineteenth century, by no means is the anti-tribal propaganda pervading those writers' treatment of law, policy, and history limited to statements concerning the 1887 General Allotment Act. In his essay "Nobody's Pet Poodle," for instance, Churchill presents a comparably erroneous and misinforming description of the Indian Arts and Crafts Act, ${ }^{93}$ a piece of legislation that, as mentioned earlier, Congress enacted in 1990 "to protect Indian artists" and, by extension, the art-buying public as well-from the effects of

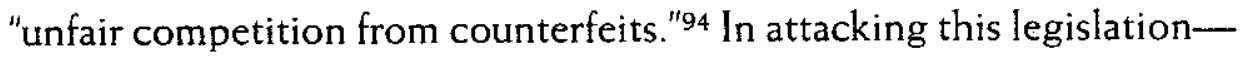
and the Indian artists and Indian rights advocates who lobbied Congress on tribes' behalf to pass it-Churchill portrays the Indian Arts and Crafts Act in the following pejorative terms:

The government "standard" involved . . is that a person can be an "American Indian artist" only if he or she is "certifiably" of "one-quarter or more degree of Indian blood by birth." Alternatively, the artist may be a member of one or another of the federally-sanctioned Indian "tribes" currently existing within the U.S..$^{95}$ 
Churchill goes on to condemn tribes as "entities" whose "membership rolls originated in the prevailing federal racial criteria of the late 19th century." 96

But quite apart from Churchill's unavailing efforts, criticized earlier, to forge a link here between tribal enrollment procedures and the General Allotment Act, Churchill's description of the Indian Arts and Crafts Act is itself erroneous-and egregiously so. Contrary to Churchill's false characterization, the Indian Arts and Crafts Act does not establishnot even as an "alternative" to tribal membership-a "standard" of "onequarter or more degree of Indian blood by birth" for any person claiming to be an "American Indian artist." In fact, the Indian Arts and Crafts Act specifies no particular minimum blood quantum requirement at all in providing civil and criminal sanctions for the selling of Indian art "in a manner that falsely suggests it is Indian produced, an Indian product, or the product of a particular Indian or Indian tribe or Indian arts and crafts organization, resident within the United States. ${ }^{197}$

Rather, to give effect to those sanctions, the act defines "Indian" as "any individual who is a member of an Indian tribe, or ... is certified as an Indian artisan by an Indian tribe. ${ }^{" 98}$ As for the phrase "an individual who ... is certified as an Indian artisan by an Indian tribe," the legislative history shows that Congress intended that phrase to mean "any individual who, although not a member of an Indian tribe, is certified by that tribe to be of the tribe's lineage." ${ }^{\prime 99}$ Consistent with the statute's broad deference to tribal self-determination in the act's definition of "Indian" for purposes of the act's protective provisions, the Department of the Interior promulgated conforming regulations in 1996. ${ }^{100}$ Like the text of the act, those regulations specify no particular minimum blood quantum requirement at all for an individual to be considered an "Indian" or an "Indian artisan" under the act. Instead, the federal regulations specify simply that an "Indian artisan" must be of the certifying tribe's lineage. ${ }^{101}$ In this way, the Indian Arts and Crafts Act wisely guards against the otherwise inevitable eventuality of nonIndians who are not members of any Indian tribe presuming to qualify as "Indians" within the meaning of the act-an eventuality that would subvert, of course, the act's core purpose of "prevent[ing] the passing off of nonIndian produced goods as Indian produced." 102

Like Churchill, Jaimes-Guerrero, too, has purported to provide her readers with information about the Indian Arts and Crafts Act, and, predictably, her treatment of the subject reads like a first draft of Churchill's substantially similar script-right down to the lockstep distortions of fact concerning the act's contents. In decrying the act as "[g]rotesque[]" and an "example of the contemporary reassertion of eugenics principles in federal Indian identification policies," 103 JaimesGuerrero interjects the following "summary" of the act's substantive provisions: 
[T] he statute legally restricts definition of American Indian artists to those possessing a federally issued "Certificate of Degree of Indian Blood" - derogatorily referred to as "pedigree slips" by opponents ${ }^{104}$ —or those certified as such by "federally recognized tribes" or the "Alaska Native Corporation." Excluded are not only those who fall below bloodquantum requirements, but anyone else who has, for politico-philosophical reasons, refused to cooperate with federal pretensions to define for itself who will and who will not be considered a member and citizen of a recognized indigenous nation. ${ }^{105}$

Despite Jaimes-Guerrero's histrionic assertions, the Indian Arts and Crafts Act makes no reference at all to any "Certificate of Degree of Indian Blood," nor does the act refer to any such thing as "the 'Alaska Native Corporation," nor does it establish any minimum blood quantum requirement for purposes of implementation. Indeed, none of these terms"blood quantum," "Alaska Native Corporation," "Certificate of Degree of Indian Blood"- appears anywhere in the text of the statute, in the statute's legislative history, or in the administrative regulations promulgated for implementing the act. ${ }^{106}$ Like Churchill, Jaimes-Guerrero simply has invented all these purported details about how the Indian Arts and Crafts Act "legally restricts definition of American Indian artists" in order to disparage Indian tribes and mislead the public about the contents and meaning of this important pro-Indian and anti-fraud legislation. ${ }^{107}$

\section{O N CL U S I O N}

What harmonizes Churchill's and Jaimes-Guerrero's misrepresentations of the Indian Arts and Crafts Act with their fabrications concerning the General Allotment Act is a shared predilection for fomenting confusion and ignorance in non-Indians' impressions about the pressing legal and political issues facing Indian tribes in the quest for tribal survival, self-determination, and enduring sovereignty in the modern world. As I have suggested elsewhere, ${ }^{108}$ this kind of confusion and ignorance puts tribes in peril with each new effort to advance in tribes' five-centuries-long struggle for social justice; for as Felix Cohen ob-

served a half century ago, "confusion and ignorance in fields of law are allies of despotism." ${ }^{109}$ And for Indian people, subjection to despotism seldom lags far behind public acceptance of disparaging falsehoods concerning the unique needs of Indian tribes as those needs have emerged and evolved in the course of tribes' historic and continuing relationship with the United States government.

In A Little Matter of Genocide, Churchill has this to say about his scholarly efforts: 
Throughout the book, I have gone out of my way to provide what Noam Chomsky has called "rich footnotes." The reasons for this are several, and devolve not merely upon the unusual scholarly fetish with indicating familiarity with "the literature." I do believe that when making many of the points l've sought to make, and with the bluntness which typically marks my work, one is welladvised to be thorough in revealing the basis upon which they rest. I also believe it is a matter not just of courtesy, but of ethics, to make proper attribution to those upon whose ideas and research one relies. Most importantly, I want those who read this book to be able to interrogate what l've said, to challenge it and consequently to build on it. The most expedient means to this end is the provision of copious annotation, citing sources both pro and con. ${ }^{110}$

These words echo an earlier bit of advice from Struggle for the Land:

Readers are urged to follow up with readings from the abundant notes. In this way, perhaps we can at last arrive at a common understanding of our common situation, the common peril which confronts us all, and a common strategy by which to eliminate it. It is, after all, our collective future which is at stake. ${ }^{11}$

Of course, the scholarly writings of Churchill and Jaimes-Guerrero are "rich," in a sense- "rich" with distortions of law, policy, and history, "rich" with subterfuge and evasion, "rich" with vicious propaganda for obstructing Indian people's efforts to secure all the respect, compassion, and support that Indian tribes deserve in the modern world. Thus, it is no small irony that Churchill himself urges readers to "follow up" and "interrogate" the "points" in his writings in pursuit of "the basis upon which they rest." For only by doing so can readers come to appreciate how Churchill's and Jaimes-Guerrero's writings really measure up as "a matter ... of ethics"—or how they give us pause to ponder indeed "the common peril which confronts us all."

\section{A P P E N D I X}

\section{Full Text of the General Allotment Act of 1887 [Act of February 8, 1887, ch. 119, 24 Stat. 388]}

CHAP. 119.-An act to provide for the allotment of lands in severalty to Indians on the various reservations, and to extend the protection of the 
laws of the United States and the Territories over the Indians, and for other purposes.

Be it enacted by the Senate and House of Representatives of the United States of America in Congress assembled, That in all cases where any tribe or band of Indians has been, or shall hereafter be, located upon any reservation created for their use, either by treaty stipulation or by virtue of an act of Congress or executive order setting apart the same for their use, the President of the United States be, and he hereby is, authorized, whenever in his opinion any reservation or any part thereof of such Indians is advantageous for agricultural or grazing purposes, to cause said reservation, or any part thereof, to be surveyed, or resurveyed if necessary, and to allot the lands in said reservation in severalty to any Indian located thereon in quantities as follows:

To each head of a family, one-quarter of a section;

To each single person over eighteen years of age, one-eighth of a section;

To each orphan child under eighteen years of age, one-eighth of a section; and

To each other single person under eighteen years now living, or who may be born prior to the date of the order of the President directing an allotment of the lands embraced in any reservation, one-sixteenth of a section: Provided, That in case there is not sufficient land in any of said reservations to allot lands to each individual of the classes above named in quantities as above provided, the lands embraced in such reservation or reservations shall be allotted to each individual of each of said classes pro rata in accordance with the provisions of this act: And provided further, That where the treaty or act of Congress setting apart such reservation provides for the allotment of lands in severalty in quantities in excess of those herein provided, the President, in making allotments upon such reservation, shall allot the lands to each individual Indian belonging thereon in quantity as specified in such treaty or act: And provided further, That when the lands allotted are only valuable for grazing purposes, an additional allotment of such grazing lands, in quantities as above provided, shall be made to each individual.

SEC. 2. That all allotments set apart under the provisions of this act shall be selected by the Indians, heads of families selecting for their minor children, and the agents shall select for each orphan child, and in such manner as to embrace the improvements of the Indians making the selection. Where the improvements of two or more Indians have been made on the same legal subdivision of land, unless they shall otherwise agree, a provisional line may be run dividing said lands between them, and the amount to which each is entitled shall be equalized in the assignment of the remainder of the land to which they are entitled under this act: Provided. That if any one entitled to an allotment shall 
fail to make a selection within four years after the President shall direct that allotments may be made on a particular reservation, the Secretary of the Interior may direct the agent of such tribe or band, if such there be, and if there be no agent, then a special agent appointed for that purpose, to make a selection for such Indian, which [s]election shal] be allotted as in cases where selections are made by the Indians, and patents shall issue in like manner.

SEC. 3. That the allotments provided for in this act shall be made by special agents appointed by the President for such purpose, and the agents in charge of the respective reservations on which the allot. ments are directed to be made, under such rules and regulations as the Secretary of the Interior may from time to time prescribe, and shall be certified by such agents to the Commissioner of Indian Affairs, in duplicate, one copy to be retained in the Indian Office and the other to be transmitted to the Secretary of the Interior for his action, and to be deposited in the General Land Office.

SEC. 4. That where any Indian not residing upon a reservation, or for whose tribe no reservation has been provided by treaty, act of Congress, or executive order, shall make settlement upon any surveyed or unsurveyed lands of the United States not otherwise appropriated, he or she shall be entitled, upon application to the local land office for the district in which the lands are located, to have the same allotted to him or her, and to his or her children, in quantities and manner as provided in this act for Indians residing upon reservations; and when such settlement is made upon unsurveyed lands, the grant to such Indians shall be adjusted upon the survey of the lands so as to conform thereto; and patents shall be issued to them for such lands in the manner and with the restrictions as herein provided. And the fees to which the officers of such local land office would have been entitled had such lands been entered under the general laws for the disposition of the public lands shall be paid to them, from any moneys in the Treasury of the United States not otherwise appropriated, upon a statement of an account in their behalf for such fees by the Commissioner of the General Land Office, and a certification of such account to the Secretary of the Treasury by the Secretary of the Interior.

SEC. 5. That upon the approval of the allotments provided for in this act by the Secretary of the Interior, he shall cause patents to issue therefor in the name of the allottees, which patents shall be of the legal effect, and declare that the United States does and will hold the land thus allotted, for the period of twenty-five years, in trust for the sole use and benefit of the Indian to whom such allotment shall have been made, or, in case of his decease, of his heirs according to the laws of the State or Territory where such land is located, and that at the expiration of said period the United States will convey the same by patent to said Indian, or his heirs as aforesaid, in fee, discharged of said trust and free 
of all charge or incumbrance whatsoever: Provided, That the President of the United States may in any case in his discretion extend the period. And if any conveyance shall be made of the lands set apart and allotted as herein provided, or any contract made touching the same, before the expiration of the time above mentioned, such conveyance or contract shall be absolutely null and void: Provided, That the law of descent and partition in force in the State or Territory where such lands are situate shall apply thereto after patents therefor have been executed and delivered, except as herein otherwise provided ${ }_{i}$ and the laws of the State of Kansas regulating the descent and partition of real estate shall, so far as practicable, apply to all lands in the Indian Territory which may be allotted in severalty under the provisions of this act: And provided further, That at any time after lands have been allotted to all the Indians of any tribe as herein provided, or sooner if in the opinion of the President it shall be for the best interests of said tribe, it shall be lawful for the Secretary of the Interior to negotiate with such Indian tribe for the purchase and release by said tribe, in conformity with the treaty or statute under which such reservation is held, of such portions of its reservation not allotted as such tribe shall, from time to time, consent to sell, on such terms and conditions as shall be considered just and equitable between the United States and said tribe of Indians, which purchase shall not be complete until ratified by Congress, and the form and manner of executing such release shall also be prescribed by Congress: Provided bowever, That all lands adapted to agriculture, with or without irrigation so sold or released to the United States by any Indian tribe shall be held by the United States for the sole purpose of securing homes to actual settlers only in tracts not exceeding one hundred and sixty acres to any one person, on such terms as Congress shall prescribe, subject to grants which Congress may make in aid of education: And provided furtber, That no patents shall issue therefor except to the person so taking the same as and for a homestead, or his heirs, and after the expiration of five years occupancy thereof as such homestead ${ }_{i}$ and any conveyance of said lands so taken as a homestead, or any contract touching the same, or lien thereon, created prior to the date of such patent, shall be null and void. And the sums agreed to be paid by the United States as purchase money for any portion of any such reservation shall be held in the Treasury of the United States for the sole use of the tribe or tribes of Indians; to whom such reservations belonged $_{i}$ and the same, with interest thereon at three per cent per annum, shall be at all times subject to appropriation by Congress for the education and civilization of such tribe or tribes of Indians or the members thereof. The patents aforesaid shall be recorded in the General Land Office, and afterward delivered, free of charge, to the allottee entitled thereto. And if any religious society or other organization is now occupying any of the public lands to which this act is 
applicable, for religious or educational work among the Indians, the Secretary of the Interior is hereby authorized to confirm such occupa. tion to such society or organization in quantity not exceeding one hundred and sixty acres in any one tract, so long as the same shall be so occupied, on such terms as he shall deem just; but nothing herein contained shall change or alter any claim of such society for religious or educational purposes heretofore granted by law. And hereafter in the employment of Indian police, or any other emloyes [sic] in the public service among any of the Indian tribes or bands affected by the act, and where Indians can perform the duties required, those Indians who have availed themselves of the provisions of this act and become citizens of the United States shall be preferred.

SEC. 6. That upon the completion of said allotments and the patenting of the lands to said allottees, each and every member of the respective bands or tribes of Indians to whom allotments have been made shall have the benefit of and be subject to the laws, both civil and criminal, of the State or Territory in which they may reside; and no Territory shall pass or enforce any law denying any such Indian within its jurisdiction the equal protection of the law. And every Indian born within the territorial limits of the United States to whom allotments shall have been made under the provisions of this act, or under any low or treaty, and every Indian born within the territorial limits of the United States who has voluntarily taken up, within said limits, his residence separate and apart from any tribe of Indians therein, and has adopted the habits of civilized life, is hereby declared to be a citizen of the United States, and is entitled to all the rights, privileges, and immunities of such citizens, whether said Indian has been or not, by birth or otherwise, a member of any tribe of Indians within the territorial limits of the United States without in any manner impairing or otherwise affecting the right of any such Indian to tribal or other property.

SEC. 7. That in cases where the use of water for irrigation is necessary to render the lands within any Indian reservation available for agricultural purposes, the Secretary of the Interior be, and he is hereby, authorized to prescribe such rules and regulations as he may deem necessary to secure a just and equal distribution thereof among the Indians residing upon any such reservations; and no other appropriation or grant of water by any riparian proprietor shall be authorized or permitted to the damage of any other riparian proprietor.

SEC. 8. That the provisions of this act shall not extend to the territory occupied by the Cherokees, Creeks, Choctaws, Chickasaws, Seminoles, and Osage, Miamies and Peorias, and Sacs and Foxes, in the Indian Territory, nor to any of the reservations of the Seneca Nation of New York Indians in the State of New York, nor to that strip of territory in the State of Nebraska adjoining the Sioux Nation on the south added by executive order. 
SEC. 9. That for the purpose of making the surveys and resurveys mentioned in section two of this act, there be, and hereby is, appropriated, out of any moneys in the Treasury not otherwise appropriated, the sum of one hundred thousand dollars, to be repaid proportionately out of the proceeds of the sales of such land as may be acquired from the Indians under the provisions of this act.

SEC. 10. That nothing in this act contained shall be so construed as to affect the right and power of Congress to grant the right of way through any lands granted to an Indian, or a tribe of Indians, for railroads or other highways, or telegraph lines, for the public use, or to condemn such lands to public uses, upon making just compensation.

SEC. 11. That nothing in this act shall be so construed as to prevent the removal of the Southern Ute Indians from their present reservation in Southwestern Colorado to a new reservation by and with the consent of a majority of the adult male members of said tribe.

Approved, February 8, 1887.

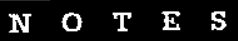

1 M. Annette Jaimes, "Federal Indian Identification Policy: A Usurpation of Indigenous Sovereignty in Native North America," in M. Annette Jaimes, ed., The State of Native America: Genocide, Colonization and Resistance (Boston: South End Press, 1992), 123-38.

2 See, for example, Joane Nagel, "The Problematics of American Indian Ethnicity," in American Indian Etbric Renewal: Red Power and the Resurgence of Identity and Culture (New York: Oxford University Press, 1996), 253 nn. 55-56 (stating that "Jaimes is highly critical of blood quantum rules for determining Indian authenticity ... and labels the American Indian Arts and Crafts Act a 'contemporary reassertion of eugenics principles," and noting further that "Jaimes reports that the required 'Certificates of Degree of Indian Blood' are 'derogatorily referred to as "pedigree slips"'" $)_{i}$ Matthew Atkinson, "Red Tape: How American Laws Ensnare Native American Lands, Resources, and People," Oklabama City University Law Review 23 (1998): 394 (citing Churchill in stating that under the
General Allotment Act, "each Indian would be allotted a tract of land in proportion to their 'blood quantum' (the first use of genetic racism to cheat Indians) $)^{\prime \prime}$; Stuart Minor Benjamin, "Equal . Protection and the Special Relationship: The Case of Native Hawaiians," Yale Law Journal 106 (1996): 569 n. 144 (citing Jaimes in stating that "[s]ome commentators have argued that ... federal government policies focusing on blood quantum have effectively racialized membership of Indian tribes"); Mark Hannig, "An Examination of the Possibility to Secure Intellectual Property Rights for Plant Genetic Resources Developed by Indigenous Peoples of the NAFTA States: Domestic Legislation under the International Convention for Protection of New Plant Varieties," Arizona Journal of International and Comparative Law 13 (1996): 179 n. 13 (citing Jaimes as having "identifie[d] historical and contemporary economic and political factors that have led to the struggle that Native North Americans face when attempting to define who they are"); Kathryn R. L. Rand and Steven A. Light, "Virtue or Vice? How IGRA 
Shapes the Politics of Native American Gaming, Sovereignty, and Identity," Virginia Joumal of Society, Policy and Law 4 (1997): 434 n. 302 (relying on and quoting Churchill in positing that "[b]y imposing more stringent blood quantum requirements in order to limit membership, gaming tribes have voluntarily impos[ed] the burden of stark racism upon themselves'" $)_{i}$ Rennard Strickland, "The Genocidal Premise in Native American Law and Policy: Exorcising Aboriginal Ghosts," Joumal of Gender, Race and Justice 1 (1998): 329 n. 24 (stating, in reliance on Jaimes's misrepresentation of the views of historian Patricia Nelson Limerick, that Limerick "concludes that a major task of Indian law and policy for the last two hundred years has been to reduce the number of Indians"), Sylvia F. Liu, Comment, "American Indian Reserved Water Rights: The Federal Obligation to Protect Tribal Water Resources and Tribal Autonomy," Environmental Law 25 (1995): 449 n. 149 (relying on Jaimes in stating that "[t] he federal government ... has undermined [tribal] sovereignty by imposing 'Indian identification standards,' typically centered upon a notion of 'blood quantum' as a basis for regulating and providing benefits for American Indians," and that "[b]lood quantum policies will eventually define Indians out of existence, due to intermarriage" ), Mark Neath, Comment, "American Indian Gaming Enterprises and Tribal Membership: Race, Exclusivity, and a Perilous Future," University of Cbicago Law Scbool Roundtable 2 (1995): 696 n. 63 (relying on Churchill in stating that "the federal government first used [blood quantum] as a direct proxy of Indian identity in the General Allotment Act of $1887^{\prime \prime}$ and that "many tribes, in response to gaming success and a shrinking pool of federal resources, have volun- tarily 'impos[ed] the burden of stark racism upon themselves'").

3 Jaimes, ed., The State of Native America, describes "Marianna Guerrero" as a "Mestiza Apache" and "the pseudonym of an indige. nous human rights activist who, for reasons of security related to her work, wishes not to be further identified at the present time," 445. Curiously, the same book identifies M. Annette Jaimes as "Juaneño/Yaqui," 446. A recently published essay by the editor of The State of Native America presents the name of the author of that essay as "Marianette JaimesGuerrero"; see Marianette JaimesGuerrero, "Savage Erotica Exotica: Media Imagery of Native Women in North America," in Renée Hulan, ed., Native Nortb America: Critical and Cultural Perspectives (Toronto: ECW Press, 1999), 187, 271.

4 The acknowledged Churchill contributions in The State of Native America are Ward Churchill and Glenn T. Morris, "Key Indian Laws and Cases," in Jaimes, ed., The State of Native America, 13-21; Ward Churchill, "The Earth Is Our Mother: Struggles for American Indian Land and Liberation in the Contemporary United States," in ibid., 139-88; The Institute for Natural Progress [Ward Churchill], "In Usual and Accustomed Places: Contemporary American Indian Fishing Rights Struggles," in ibid., 217-39, Ward Churchill and Winona LaDuke, "Native North America: The Political Economy of Radioactive Colonialism," in ibid., 241-66. Churchill's authorship of the essay stated to be a product of The Institute for Natural Progress is made clear at the end of The State of Native America in "About the Contributors"; there, Churchill is identified as having "assumed the lead role in preparing the INP contribution to this volume," 446. 
5 For a discussion of Churchill's anti-tribal ideology as reflected in Churchill's book Indians Are Us? see John LaVelle, "Review Essay: Indians Are Us?" American Indian Quarterly 20, 1 (winter 1996): 109-18.

6 Marianna Guerrero [pseud.], "American Indian Water Rights: The Blood of Life in Native North America," in Jaimes, ed., The State of Native America, 189-216. The pseudonym "Marianna Guerrero" also appears on the back cover of Churchill's book Indians Are Us? Culture and Genocide in Native Nortb America (Monroe, Maine: Common Courage Press, 1994), where "Guerrero," purportedly writing for Bloomsbury Review, praises Churchill in the following terms: "The name Ward Churchill has become increasingly prominent in matters related to American Indian rights during the past decade. Most of this standing . . has to do with the caliber of his writing and analysis," (alteration in original). As an added wrinkle to the "Marianna Guerrero" intrigue, it should be noted further that as editor of Churchill's book Fantasies of the Master Race. "M. Annette Jaimes" appears to have dedicated the role she played in the making of that book to a family member whose surname is stated to be "Guerrero." See Ward Churchill, Fantasies of the Master Race: Literature, Cinema and the Colonization of the American Indians, ed. M. Annette Jaimes (Monroe, Maine: Common Courage Press, 1992), dedication page.

7 See Ward Churchill, Struggle for the Land: Indigenous Resistance to Genocide, Ecocide and Expropriation in Contemporary Nortb America (Monroe, Maine: Common Courage Press, 1993); Churchill, Indians Are Us?

8 Compare, for example, the following similar passages-the first from Churchill, "Perversions of Justice: Examining the Doctrine of U.S. Rights to Occupancy in North America," in Struggle for the Land, and the second from Rebecca L. Robbins, "Self. Determination and Subordination: The Past, Present and Future of American Indian Governance," in Jaimes, ed., The State of Native America. Churchill writes:

"A little discussed aspect of the Allotment Act is that it required each Indian, as a condition of receiving the deed to his or her land parcel, to accept U.S. citizenship. By the early 1920s, when most of the allotment the U.S. wished to accomplish had been completed, there were still a significant number of native people who still had not been 'naturalized,' either because they'd been left out of the process for one reason or another, or because they'd refused to participate. Consequently, in 1924 the Congress passed a 'clean up bill,' the Indian Citizenship Act, which imposed citizenship upon all remaining indigenous people within U.S. borders whether they wished it or not" $(50-51)$. Immediately following this paragraph, Churchill appends a single endnote that cites the Indian Citizenship Act but does not cite Robbins (75 n. 71.) But in point of fact, Churchill's citation to the Indian Citizenship Act is erroneous and refers instead to obsolete and non-codified provisions from United States Statutes at Large granting the consent of Congress for the construction of bridges across two navigable watercourses.

Robbins concludes a longer paragraph with the following words: "Hence, one little-noted aspect of the General Allotment Act was that it required each 'qualified' Indian (i.e., those of 'mixed blood'), in order to receive the deed to his or her parcel of land, to accept U.S. citizenship, a circumstance which served to further confuse the already garbled identities and loyalties of recipients. In 1924, Congress 
completed this process by passing a 'clean-up' measure, the Indian Citizenship Act, unilaterally conferring American citizenship upon all native people-whether they desired it or not-who had not otherwise been nationalized as part of the U.S. population" (93). Robbins includes an endnote after each of the two sentences in this passage, but neither of them mentions Churchill (116 nn. 49,50).

Another illustration of the interchangeability of rhetoric in The State of Native America with that found in Churchill's separate writings is the following juxtaposition of passages, the first from JaimesGuerrero, "Federal Indian Identification Policy" (1992), and the second from Churchill, "Perversions of Justice" (1993). Jaimes writes:

"The Indian Citizenship Act greatly confused the circumstances even of many of the blooded and federally certified Indians insofar as it was held to bear legal force, and to carry legal obligations, whether or not any given Indian or group of Indians wished to be a U.S. citizen. As for the host of non-certified, mixed-blood people residing in the U.S., their status was 'clarified'; they had been definitionally absorbed into the American mainstream at the stroke of the congressional pen. And, despite the fact that the act technically left certified Indians occupying the status of citizenship in their own indigenous nation as well as in the U.S. (a 'dual form' of citizenship so awkward as to be sublime), the juridical door had been opened by which the weight of Indian obligations would begin to accrue more to the U.S. than to themselves" (127-28).

Churchill writes:

"The Indian Citizenship Act greatly confused the circumstances even of many of the blooded and federally-certified Indians insofar as it was held to bear legal force, and imposed legal obligations of citizenship upon them. As for the host of noncertified, mixed-blood people, their status was finally 'clarified': they had been absorbed into the American mainstream at the stroke of the congressional pen. Despite the act having tech. nically left certified Indians oc. cupying the status of citizenship within their own indigenous na. tion as well as the U.S. (a 'dual form' of citizenship so awkward as to be sublime), the juridical door had been opened by which the weight of Indian obligations would begin to accrue more to the U.S. than to themselves" (51). While Churchill appends a brief citation to the pages from The State of Native America on which the corresponding Jaimes passage is located ( 75 n. 72), he fails to indicate that he in fact copied his entire paragraph in virtual verbatim form from Jaimes's essay.

For additional examples of the wholesale "borrowing" without adequate citation of passages from essays written by authors other than Churchill and published in The State of Native America and passages from Churchill's other writings, compare the paragraph beginning "The Allotment Act set forth" in Robbins, "Self-Determination and Subordination," 93, with the paragraph beginning "The Allotment Act stipulated" in Churchill, "Perversions of Justice," 49 ; compare also the two consecutive paragraphs beginning "A bit earlier" in Robbins, "Self-Determination and Subordination," 93-94, with the paragraph beginning "For nearly a generation" in Churchill, "Cenocide in Arizona? The Navajo-Hopi Land Dispute' in Perspective," in Struggle for the Land, 145, and with the two consecutive paragraphs beginning "The origins of what is passed off" in Churchill, "American Indian Self-Governance: Fact, Fantasy and Prospects for the Future," in ibid., 380-82.

A related problem is Churchill's apparent "borrowing" without 
proper attribution of an entire essay by Canadian scholar Fay G. Cohen. Cohen's essay, titled "Implementing Indian Treaty Fishing Rights: Conflicts and Cooperation," originally was published in 1991 in a collection edited by Churchill, Critical Issues in Native North America, vol. 2. ([Copenhagen: International Work Group for Indigenous Affairs, 1991], IWGIA Doc. 68). But in Jaimes-Guerrero's 1992 book The State of Native America, there appears an essay titled "In Usual and Accustomed Places," stated to have been "prepared" by Churchill on behalf of "The Institute for Natural Progress," which pervasively reproduces in slightly altered form numerous passages from Cohen's essay without giving any indication of Cohen's authorship. Thus, for example, Cohen's essay contains the following paragraph:

"The formation and strategy of the Northwest Water Resources Committee provides an illustration of how the process of change occurred. Established by major Northwest timber, utility and banking companies, this committee wanted to assess the implications of a 1980 ruling in Phase II, which supported the concept of environmental protection for treaty fisheries. The industrialists were concerned about the limits that such protection might place on future development and about the uncertainty it could engender. They hired an attorney who had previously worked on treaty issues. His analysis highlighted the record of legal losses suffered by treaty opponents. He outlined the available options and recommended direct negotiations with tribes. The corporations agreed." (160-61)

Similarly, a paragraph from "In Usual and Accustomed Places," by "The Institute for Natural Progress" states the following:
"The formation and strategy of the Northwest Water Resources Committee (NWRC) offers a useful illustration of how the process has evolved. Created in 1981 by major timber, utility and banking concerns, NWRC set out to assess the implications of a 1980 ruling in U.S. v. Washington (Pbase II), which endorsed the concept of environmental protection for native fisheries. NWRC was concerned about the limits such protection might place on future development and about the uncertainty it could engender among potential investors. The committee hired James Waldo, an attorney experienced in treaty litigation, to study the matter. His analysis highlighted the record of legal losses suffered by treaty opponents, outlined the options available to NWRC, and recommended direct negotiations with indigenous nations. The corporation agreed" (229-30).

Additional similarities between Cohen's and Churchill's essays abound. In comparing the two essays generally, it should be noted further that Churchill does indeed mention Cohen's scholarshipalthough Churchill misspells Cohen's first name as "Faye" in an accompanying endnote-in the first paragraph of his essay, as follows:

"[D]etailed analysis of the situation in the Pacific Northwest may be found in Uncommon Controversy: Fishing Rights of the Mucklesboot, Puyallup and Nisqually Indians (1970), Indian Tribes: A Continuing Quest for Survival (1981), and Treaties on Trial: The Continuing Controversy over Nortbwest Indian Fisbing Rigbts (1986)" (217).

However, this reference by Churchill to Cohen's book Treaties on Trial really is little more than a copy of Cohen's own reference to that book in the first paragraph of the essay from which Churchill "borrowed," for in that earlier essay of hers, Cohen writes: 
"Detailed analysis of the Northwest Indian treaty fisheries controversy may be found in Uncommon Controversy: Fishing Rigbts of the Mucklesboot, Puyallup and Nisqually Indians; Indian Tribes: A Continuing Quest for Survival; and Treaties on Trial: The Continuing Controversy over Nortbwest Indian Fisbing Rights" (154).

9 Act of Feb. 8, 1887, ch. 119, 24 Stat. 388 (codified as amended at 25 U.S. Code secs. 331-334, 339, $341,342,348,349,354,381$ ).

10 Act of June 18,1934 , ch. 576,48 Stat. 984 (codified as amended at 25 U.S. Code secs. 461, 462, 463, $464,465,466-470,471-473,474$, $475,476-478,479)$. The provision of the Indian Reorganization Act that ended the allotment process reads as follows: "On and after June 18,1934, no land of any Indian reservation, created or set apart by treaty or agreement with the Indians, Act of Congress, Executive order, purchase, or otherwise, shall be allotted in severalty to any Indian" (25 U.S. Code sec. 461). See Felix S. Coben's Handbook of Federal Indian Law. 1982 ed., ed. Rennard Strickland et al. (Charlottesville, N.C.: Michie, 1982), 138.

11 Jaimes, "Federal Indian Identification Policy," 126-27 (emphases in original).

12 Ibid., 129.

13 Ibid., 136-37.

14 The full text of the General Allotment Act of 1887, as originally enacted by Congress and published in United States Statutes at Large, is reprinted as an appendix at the end of this essay. United States Code Annotated (U.S.C.A.) is a set of volumes published by West Publishing Company that contains all the federal statutes found in the United States Code (U.S. Code or U.S.C.) - the of- ficial, comprehensive multivolume publication of all legislation en. acted by Congress into general and permanent law-as well as numerous "case notes of state and federal [court] decisions which construe and apply specific Code sections, cross-references to related sections, historical notes, and library references." Joseph $R$. Nolan et al., Black's Law Dictionary, 6th ed. (St. Paul: West Publishing Co., 1990), 1534 (defining "United States Code Annotated"). Other primary sources of federal law referred to in the present essay are the following:

United States Statutes at Large (Stat.). As stated in Black's Law Dictionary, this is the federal gov. ernment's "official compilation of the acts and resolutions of each session of Congress published by the Office of the Federal Register in the National Archives and Records Service. ... The arrangement is currently by Public Law [P.L.] number, and by chapter number in pre-1951 volumes. This is the official print of the law for citation purposes where titles of the United States Code have not been enacted into positive law." Ibid., 1411 (defining "Statutes at large").

Code of Federal Regulations (C.F.R.). Black's defines this as "the annual cumulation of executive agency regulations published in the daily Federal Register, combined with regulations issued previously that are still in effect. ... The CFR contains the general body of regulatory laws governing practice and procedure before federal administrative agencies." lbid., 257 (defining "Code of Federal Regulations").

United States Code Congressional and Administrative News (U.S. Code Cong. and Adm. News). This is a multivolume supplement to United States Code Annotated that contains, among other things, the legislative histories of significant federal bills enacted into law. See ibid., 
1534 (defining "United States Code Annotated").

15 All of the following summaries in the text of the provisions of the act quote from and are based on 25 U.S.C.A. (St. Paul: West, 1983).

16 This provision's specifications of the quantities and types of land to be assigned to each allottee originated as amendments to the General Allotment Act. See Act of February 28, 1891, ch. 383, sec. 1 , 26 Stat. 794; Act of June 25, 1910, ch. 431 , sec. 17,36 Stat. 859 .

17 Act of May 8, 1906, ch. 2348, 34 Stat. 182 (codified at 25 U.S.C.A. sec. 349 [West, 1983]).

18 Act of June 2,1924, ch. 233,43 Stat. 253 (superseded 1940) (codified as amended and carried forward at 8 U.S. Code sec. 1401(b)).

19 See 25 U.S.C.A. sec. 349 (West, 1983) and accompanying "Historical Note" on "Codification."

20 The fourth section of the General Allotment Act of 1887 is codified, as amended, at 25 U.S.C.A. sec. 334 (West, 1983). See also the full text of the General Allotment Act of 1887 , reprinted as an appendix at the end of this essay.

2143 C.F.R. sec. 2531.1(a) (1998).

22 lbid.

2325 U.S.C.A. sec. 345 (West, 1983) (codifying provisions of Appropriations Act of Aug. 15, 1894, ch. 290 , sec. 1, 28 Stat. 305 , as amended by the Act of Feb. 6 , 1901, ch. 217, sec. 1, 31 Stat. 760 , and by the Act of Mar. 3, 1911, ch. 231 , sec. 291,36 Stat. 1167). In full, this provision of U.S.C.A. captioned as "Actions for allotments" states as follows:

"All persons who are in whole or in part of Indian blood or descent who are entitled to an allotment of land under any law of Congress, or who claim to be so entitled to land under any allotment Act or under any grant made by Congress, or who claim to have been unlawfully denied or excluded from any allotment or any parcel of land to which they claim to be lawfully entitled by virtue of any Act of Congress, may commence and prosecute or defend any action, suit, or proceeding in relation to their right thereto in the proper district court of the United States; and said district courts are given jurisdiction to try and determine any action, suit, or proceeding arising within their respective jurisdictions involving the right of any person, in whole or in part of Indian blood or descent, to any allotment of land under any law or treaty (and in said suit the parties thereto shall be the claimant as plaintiff and the United States as party defendant); and the judgment or decree of any such court in favor of any claimant to an allotment of land shall have the same effect, when properly certified to the Secretary of the Interior, as if such allotment had been allowed and approved by him, but this provision shall not apply to any lands held August 15,1894 , by either of the Five Civilized Tribes, nor to any of the lands within the Quapaw Indian Agency: Provided, That the right of appeal shall be allowed to either party as in other cases."

See generally the discussion of "Allotment Jurisdiction" in Felix $S$. Coben's Handbook of Federal Indian Law, 1982 ed., 313-16.

24 American Jurisprudence $2 \mathrm{~d}, 41 \mathrm{sec} .82$ (Indians) (1995) (citing the General Allotment Act, 25 U.S.C.A. sec. 331 et seq.; Hy-Yu-Tse-Mil-Kin v. Smith, 194 U.S. 401 [1904]).

25 Jaimes, "Federal Indian Identification Policy," 129.

26 Rennard Strickland provides a compelling analysis of allotment 
policy as "an example of legal cultural genocide" in Rennard Strickland, "Genocide-at-Law: An Historic and Contemporary View of the Native American Experience," Kansas Law Review 34 (1986): 721-35. For another excellent analysis of the devastating effects of allotment policy on Indian tribes, both as a historical matter and in terms of recent decisions of the U.S. Supreme Court improperly giving new and sweeping effect to that policy, see Judith Royster, "The Legacy of Allotment," Arizona State Law Joumal 27 (1995). Royster writes:

"[Allotment's] legacy lingers on, and in recent years has been revived by the Court in a series of cases that give present effect to the discredited policy of allotment and assimilation. In the process, the Court has chosen to diminish tribal territories and to restrict tribal sovereign control over the territory that remains. By deciding cases in accord with the assimilation policy, the Court has undercut the sovereignty and territorial integrity of the Indian nations....

"... Shall we ... continue to give effect to the policy of allotment, recognized as a failure and a disaster for the tribes, officially repudiated by Congress, and contrary to every manifestation of current Indian policy? Unfortunately, the answer from the Supreme Court appears to be yes. It not only persists in giving effect to a policy that has failed, but does so in ways that disrespect the branch of government charged with authority over Indian affairs and mock the Court's own precedents in that field" (6-7).

27 The sovereign right of Indian tribes to determine their own members has been recognized numerous times by the U.S. Supreme Court. Thus, in the Cherokee Intermarriage Cases, 203 U.S. 76 (1906), the Court averted to "[ $t]$ he laws and usages of the
Cherokees" in concluding that certain non-Indians were not entitled, by virtue of the mere fact of having been married at one time to Cherokee citizens by blood, to share in a distribution of Cherokee property. The Court asserted that "[ $t$ ] he laws and usages of the Cherokees, their earliest history, the fundamental principles of their national policy, their constitution and statutes, all show that citizenship rested on blood or marriage; that the man who would assert citizenship must establish marriage; that when marriage ceased (with a special reservation in favor of widows or widowers), citizenship ceased that when an intermarried white married a person having no rights of Cherokee citizenship by blood it was conclusive evidence that the tie which bound him to the Cherokee people was severed and the very basis of his citizenship obliterated" (95). Likewise, in Santa Clara Pueblo v. Martinez, 436 U.S. 49 (1978), the Court listed tribes' power to determine their own members when affirming that "Indian tribes 'are distinct, independent political communities, retaining their original natural rights' in matters of local selfgovernment," including the "power to make their own substantive law in internal matters." (55-56) (quoting Worcester v. Georgia, 31 U.S. (6 Pet.) 515, 559 [1832]).

For a discussion of the right of Indian tribes to determine their own members as a fundamental principle of federal Indian law, see the section titled "Tribal Power to Determine Membership" in "The Field of Indian Law: Indian Tribes, Indians, and Indian Country," chap. 1 in Felix S. Coben's Handbook of Federal Indian Law, 1982 ed., 20-23. As elaborated in that discussion from the Handbook, "[t]he courts have consistently recognized that one of an Indian tribe's most basic powers is the authority to determine questions of its own 
membership.... The power of an Indian tribe to determine questions of its own membership derives from the character of an Indian tribe as a distinct political entity" (20).

28 Act of May 8, 1906, ch. 2348, 34 Stat. 182 (codified at 25 U.S.C.A. sec. 349 [West, 1983]).

29 Janet A. McDonnell, The Dispossession of the American Indian, 1887-1934 (Bloomington and Indianapolis: Indiana University Press, 1991), 104. McDonnell also points out that in 1919 Commissioner Sells, in response to critics who desired to accelerate the dispossession of Indian lands, "liberalized his policy even further" by ordering his superintendents to include in the lists of potential fee patentees not only allottees of "less than onehalf Indian blood" but also those "with exactly one-half Indian blood" (107).

30 Ibid., 109, 112. McDonnell points out that while the policy of using blood quantum to determine "competency" effectively ended in 1920 , that policy was not officially abandoned until the following year: "In 1921, the Indian Office formally rejected the practice of issuing blanket fee patents to all Indians with one-half or less Indian blood and emphasized instead Payne's earlier policy of requiring a formal application and proof of competency" (112).

31 Ibid., 110.

32 Jaimes, "Federal Indian Identification Policy," 126 (emphasis in original).

33. As one commentator has pointed out, while many nineteenthcentury legislators who endorsed allotment policy publicly espoused a "philanthropic aim" ofironically-" protect[ing] the Indian in his present land holding," a more devious "aim" also may be discerned in Congress's contriv- ance of that policy: "[D]oubters of the allotment system could see nothing in the policy but dire consequences for the Indian. Senator Teller in 1881 called the Coke bill [a precursor to the General Allotment Act]'a bill to despoil the lndians of their lands and to make them vagabonds on the face of the earth.' At another time he said, 'If I stand alone in the Senate, I want to put upon the record my prophecy in this matter, that when 30 or 40 years shall have passed and these Indians shall have parted with their title, they will curse the hand that was raised professedly in their defense to secure this kind of legisiation and if the people who are clamoring for it understood Indian character, and Indian laws, and Indian morals, and Indian religion, they would not be here clamoring for this at all.' ...

"Senator Teller had charged that allotment was in the interests of the land-grabbing speculators, but the minority report of the House Indian Affairs Committee in 1880 had gone even further in its accusations. It said:

The real aim of this bill is to get at the Indian lands and open them up to settlement. The provisions for the apparent benefit of the Indian are but the pretext to get at his lands and occupy them... If this were done in the name of greed, it would be bad enough; but to do it in the name of humanity, and under the cloak of an ardent desire to promote the Indian's welfare by making him like ourselves whether he will or not, is infinitely worse....

"It is probable that the most powerful force motivating the allotment policy was the pressure of the land-hungry western settlers."

Delos Sacket Otis, "History of the Allotment Policy, "Hearings on H.R. 7902 before the House 
Committee on Indian Affairs, $73 \mathrm{~d}$

Cong., $2 d$ Sess., pt. 9 at 428-85

(1934), reprinted in David H.

Getches, Charles F. Wilkinson, and Robert A. Williams Jr., Cases and Materials on Federal Indian Law. 4th ed. (St. Paul: West Publishing Co., 1998), 168-69.

34 Most prominent is the lengthy reference in the "Historical Note" immediately following the text of 25 U.S.C.A. sec 331 (West, 1983) concerning the extraordinarily complex series of acts passed by Congress from 1906 to 1978 pertaining to federal supervision of the oil-rich lands of members of the Osage Tribe of Oklahomaone of the tribes that had been expressly exempted from the applicability of the General Allotment Act itself. See 25 U.S.C.A. sec. 339 (West, 1983) ("The provisions of [the General Allotment Act] shall not extend to the territory occupied by [inter alia] the ... Osage . . . in Oklahoma. ..."). Because of special, complicated circumstances in the history of federal supervision of Osage lands, . Congress periodically has enacted legislation to curb the effects, at least in part, of previously enacted legislation that had enabled these rights in land-including valuable mineral estates known as "headrights" - to pass out of Osage ownership and control; and in enacting such corrective legislation, Congress has made reference at times to categories of persons of different percentages of Osage blood, including those "of onehalf or more Indian blood." Thus, the notes and references accompanying the codified provisions of the General Allotment Act occasionally invoke that language as well.

In the original edition of his Handbook of Federal Indian Law, Felix Cohen provides an illustration of the unique predicament facing the Osage Tribe, and of Congress's response in view of that predica- ment: "As oil production of the Osage Reservation increased and Osage headrights became more valuable, Osage Indians became increasingly attractive to individu. als seeking wealthy husbands or wives, and the Osage tribe be. came gravely concerned at the passing of Osage wealth out of the tribe by the process of inheritance. Congress attempted to meet this problem in section 7 of the 1925 act, as follows:

Hereafter, none but heirs of Indian blood shall inherit from those who are of one-half or more Indian blood of the Osage Tribe of Indians any right, title, or interest to any restricted lands, moneys, or mineral interests of the Osage Tribe: Provided, That this section shall not apply to spouses under existing marriages."

Felix S. Coben's Handbook of Federal Indian Law, 1942 ed. (1942; reprint, with a new foreword by Robert L. Bennett and Frederick M. Hart, Albuquerque: University of New Mexico Press, n.d.), 449 (citing and quoting from Act of February 27, 1925, 43 Stat. 1008, 1011 , amending Act of Mar. 3, 1921, 41 Stat. 1249).

For an in-depth discussion of the complicated subject of special property laws applying to the Osage Tribe, see Felix S. Coben's Handbook of Federal Indian Law, 1982 ed., 788-97.

35 As explained in Felix S. Coben's Handbook of Federal Indian Law, 1982 ed., "[g]enerally, the individual's right to share in tribal property is conditioned upon tribal membership"; and although "[ $t]$ he federal government at times has exercised its power to grant or deny certain classes of persons the right to share in tribal property," it is also the case that "Congress has never sought to impose on a tribe a property distribution scheme basically at odds with tribal 
membership laws. This would be of doubtful validity under the Constitution" $(607,608,609)$.

36 Lenore A. Stiffarm and Phil Lane Jr., "The Demography of Native North America: A Question of American Indian Survival," in Jaimes, ed., The State of Native America, 40.

37 Churchill and Morris, "Key Indian Laws and Cases," in Jaimes, ed., The State of Native America, 14.

38 More interesting, perhaps, is the fact that in "Key Indian Laws and Cases," Churchill and Morris fail even to cite the Jaimes-Guerrero essay as the source for their "summary" of the General Allotment Act. This would suggest that Jaimes-Guerrero was not the sole originator of this false General Allotment Act "eligibility" scheme, since this scheme surfaced in botb of these simultaneously published pieces in The State of Native America, with each independently authored essay neglecting to indicate any reliance on the other as the origin of this scheme.

39 Churchill, "Perversions of Justice," 49.

40 Ibid., 74 n. 64 . The related problem of citing an entire book, without specifying any particular pages, as "support" for specific assertions of fact is a recurring deficiency in Churchill's writings, as I will discuss further later on.

41 lbid.

42 Ibid., 49.

43 In a later paragraph from "Per. versions of Justice," Churchill purports to invoke languagewithout citing or identifying any particular text-from the writings of historians Patricia Nelson Limerick and Russell Thornton in an attempt to show scholarly "support" for his assertions about the effects of the nonexistent "federal eugenics criteria" of the General Allotment Act. Churchill writes: "Juaneño/Yaqui scholar M. Annette Jaimes has revealed that the U.S. government is engaged in 'a sort of statistical extermination' whereby the government seeks to eventually resolve its 'Indian problem' altogether. As historian Patricia Nelson Limerick frames it: "Set the blood quantum at one-quarter, hold to it as a rigid definition of Indians ["Indianness" in Limerick's original], let intermarriage proceed as it has ["had" in Limerick's original] for centuries, and eventually Indians will be defined out of existence.' ... Cherokee demographer Russell Thornton estimates that, given continued imposition of purely racial definitions, Native America as a whole will have disappeared by the year 2080" (51-52). Here, Churchill provides no indication-by endnote citations or otherwise-of where the quote purported to be from Limerick or the "estimate" purported to be from Thornton may be found. Because the paragraph from "Perversions of Justice" in which Churchill purports to rely on Limerick and Thornton resurfaces in substantially verbatim form in Churchill's next book, Indians Are $U_{s}$ ? - but with indicators there of the exact texts and page numbers presumably relied on-that alleged reliance is analyzed in the next section of this essay.

44 Ward Churchill, "American Indian Self-Governance: Fact, Fantasy and Prospects for the Future, ${ }^{\text {" in }}$ Struggle for the Land, 383.

45 Ibid., 396 n. 18.

46 Ward Churchill, "I Am Indigenist: Notes on the Ideology of the Fourth World," in Struggle for the Land, 403.

47 Ibid., 421 (emphasis in original). 
49 Ward Churchill, "Bringing the Law Home: Application of the Genocide Convention in the United States," in Indians Are Us? 42.

50 Ibid., 62 n. 97.

51 Actually, Churchill's first attempt at positing reliance on the writings of both Patricia Nelson Limerick and Russell Thornton, albeit without specifying works or page numbers, had occurred earlier, in Churchill's book Struggle for the Land. For a previously published discussion of Churchill's misrepresentation of the writings of Limerick and Thornton, see LaVelle, "Review Essay: Indians Are Us?" 110-12.

52 Patricia Nelson Limerick, The Legacy of Conquest: The Unbroken Past of the American West (New York: W. W. Norton Publishers, 1987).

53 Churchill, "Bringing the Law Home," 42 (quoting Limerick, The Legacy of Conquest, 338) (alteration in original). In her original text, reproduced at note 54 below, Limerick places a period inside the quoted words "Indian problem," not where Churchill places the period in his altered version of the Limerick passage. The last sentence of this excerpt from Indians Are Us? - beginning with the word "Ultimately" - is

Churchill's commentary, not Limerick's.

Note that in the present discussion of Churchill's and JaimesGuerrero's purported reliance on the passage from Limerick, corrections are inserted in brackets to flag instances in which Churchill and Jaimes-Guerrero have altered, without any indicator, the words used by Limerick in her original text. With respect to these errors as they appear in Churchill's essays, they would seem to suggest that Churchill has derived this purported reliance, without comment, directly from Jaimes-
Guerrero's previously published "Federal Indian Identification Policy," which contains essentially identical errors in its excerpt from Limerick.

54 A comparison between Churchill's excerpt and the extended, actual passage from Limerick's book clearly shows Churchill's out-of. context misrepresentation. Limerick writes: "[T]he Reagan administration's strategy was one of cutting eligibility. In a proposal in 1986, the Indian Health Service announced a plan to change the definition of Indian. If the new definition went through, an Indian would be 'a person who is a member of a federally recognized tribe, or eligible to be a member, lives on or near a reservation, and has at least one-quarter Indian blood.' It was this matter of the blood quantum that aroused the most controversy. An essential element of a tribe's sovereignty, Indian leaders argued, was the power to determine its own membership. From that angle, the revised definitions of the Indian Health Service threatened to crack the bedrock of tribal selfdetermination. Moreover, the change carried the added threat of making Indianness a racial definition rather than a category of political nationality. Set the bloodquantum at one-quarter, hold to it as a rigid definition of Indianness, let intermarriage proceed as it had for centuries, and eventually Indians will be defined out of existence. When that happens, the federal government will finally be free of its persistent 'Indian problem'"(Legacy of Conquest, 337-38).

55 See Ward Churchill, "Nobody's Pet Poodle," in Indians Are Us? 91-94; Indian Arts and Crafts Act of 1990, Pub. L. No. 101-644, 104 Stat. 4662 (codified at 25 U.S.C.A. secs. 305d, 305e [West Supp., 1998]; as amendments to 25 U.S.C.A. sec. 305a [West Supp., 
1998] and 18 U.S.C.A. secs. 1158 , 1159 [West Supp., 1998]; and as provisions set out as notes at 25 U.S.C.A. secs. 305, 305e [West Supp., 1998]).

For an informative discussion of the concerns of Indian tribes and Indian artists that provided impetus for passage of the Indian Arts and Crafts Act, see Suzan Shown Harjo, "Tribal and Cultural Identity: The Case of the Indian Arts and Crafts Act," Artpaper 13,2 (Oct. 1993): 9-11. Harjo writes: "The real point of contention in the Indian Arts and Crafts Act is cash. A 1985 U.S. Department of Commerce report estimated that 10-20 percent of the annual $\$ 400$ 500 million Indian arts and crafts market was being lost to other countries because of imported products. No official estimates are available on the loss to Native artists themselves from domestic counterfeits and artisans claiming to belong to Indian nations that do not claim them" (10).

56 Churchill, "Nobody's Pet Poodle," 92.

57 Actually, prior to any mention of Limerick by Churchill, JaimesGuerrero berself had presumed to derive support for the General Allotment Act "eligibility" scheme from Limerick. In "Federal Indian Identification Policy," JaimesGuerrero writes: "The eventual outcome of federal blood-quantum policies can be described as little other than genocidal in their final implications. As historian Patricia Nelson Limerick recently summarized the process:

Set the blood quantum at onequarter, hold to it as a rigid definition of Indians ["Indianness" in Limerick's original], let intermarriage proceed as it had for centuries, and eventually Indians will be defined out of existence. When that happens, the federal government will be freed ["will finally be free" in Limerick's original] of its persistent 'Indian problem." (132; quoting Limerick, Legacy of Conquest, 338)

In neither of the instances in Indians Are Us? nor in the addi. tional instance in Struggle for the Land, wherein he contrives a reliance on the Limerick quote, does Churchill disclose that he is deriving this particular ploy directly from the previously published essay by Jaimes-Guerrero.

58 Churchill, "Nobody's Pet Poodle," 92-93 (quoting Limerick, Legacy of Conquest, 338). It should be noted once again that the paragraph in Indians Are $U_{s}$ ? from which this passage is excerpted appears in substantially identical form, absent references to the other authors' texts and corresponding page numbers purportedly relied on, in Churchill, "Perversions of Justice," in Struggle for the Land, 51-52.

59 Russell Thornton, American Indian Holocaust and Survival: A Population History since 1492 (Norman: University of Oklahoma Press, 1987).

60 At the end of the same paragraph in "Nobody's Pet Poodle" in which Churchill relies on JaimesGuerrero and distorts Limerick, Churchill adds: "Cherokee demographer Russell Thornton estimates that, given continued imposition of purely racial definitions, Native America as a whole will have disappeared by the year 2080" (93, citing Thornton, American Indian Holocaust and Survival, 174-82). As previously indicated, a paragraph that is virtually identical to this one from "Nobody's Pet Poodle" may be found in Churchill's essay "Perversions of Justice," in Struggle for the Land.

61 Churchill, "Nobody's Pet Poodle," 109 n. 4.

62 Thornton begins the chapter containing the pages cited by 
Churchill-a chapter titled

"American Indian Population

Recovery: 1900 to Today"-by

pointing out that "[ $\mathrm{s}]$ ince around

the turn of the century American

Indians have made a remarkable

population recovery as a result of their greatly improved demographic situation" (American Indian Holocaust and Survival, 159). In a passage from that chapter under the heading "A Look to the Future," Thornton discusses various kinds of projections that are "used to illustrate what a future population size might be" (182). Thornton writes: "The American Indian population has already increased by about 70 percent from 1970 to 1980 . If this rate of growth from 1970 to 1980 were to continue to the year 2000 , the size of the American Indian population then will surpass 4 million. But, it will likely not continue. Recently, the U.S. Office of Technology Assessment published projections of the American Indian population based on data from the Bureau of Indian Affairs. One projection is that the American Indian population will not increase to around 4 million until the year 2020. (Similarly, the total United States population for the year 2025 is projected to be over 300 million.) It is also projected, however, that the American Indian population will increase to almost 16 million by the year $2080^{\prime \prime}$ (182; citing Matthew C. Snipp, The First of This Land: Native Americans in the Late Twentietb Century [tentative title] [New York: Basic Books, n.d.]; U.S. Congress, Office of Technology Assessment, Indian Health Care, OTA-H-290 [Washington, D.C.: U.S. Government Printing Office, 1986], 78, U.S. Bureau of the Census, Statistical Abstract of the United States, 1982-1983 [Washington, D.C.: Government Printing Office, 1982-83], 8).

63 For additional criticism of Churchill's case against the word tribe, see LaVelle, "Review Essay,"
$114-16$.

64 Ward Churchill, "Naming Our Destiny: Toward a Language of American Indian Liberation," in Indians Are Us? 295.

65 lbid., 295-96.

66 Ibid., 333 n. 4.

67 Ward Churchill, Since Predator Came: Notes on the Struggle for American Indian Liberation (Littleton, Colo.: Aigis Press, 1995), Ward Churchill, From a Native Son: Selected Essays on Indigenism, 1985-1995 (Boston: South End Press, 1996); Ward Churchill, A Little Matter of Genocide: Holocaust and Denial in the Americas 1492 to the Present (San Francisco: City Lights Books, 1997).

68 In Churchill's anthology From a Native Son, published the year after Since Predator Came, the word "and" in this passage is silently replaced with the word "or". See Churchill, "Since Predator Came: A Survey of Native North America since 1492," in From a Native Son, 26.

69 Ward Churchill, "Since Predator Came: A Survey of Native North America since 1492," in Since Predator Came, 31.

70 Ibid., 37 n. 29.

71 lbid., 37 n. 32 (citing George M. Frederickson, White Supremacy: A Comparative Study in American and South African History [New York: Oxford University Press, 1981]).

72 In a careful, detailed explanation of his book's methodology, Frederickson stresses the importance of "the comparative historian's concern for detail and specificity" as well as the countervailing need for the historian to move beyond "parochial vision" to achieve a "genuinely comparative insight" when examining societies whose sociological and po- 
litical histories are both similar and different (Frederickson, White Supremacy, xiv-xv). Frederickson explains further: "To achieve a coherent organization and analysis of a vast body of subject matter, I have broken down the history of white supremacy in the United States and South Africa into parallel phases or aspects, associated more or less with specific periods and sometimes with individual sections or provinces.... [F]ruitful is a juxtaposition of the roughly analogous political conflicts and assertions of national identity among whites in the period from 1776 to 1910 in terms of their effect on the status and expectations of nonwhites.... [T] his comparison reveals the crucial relevance of white political activity to the fate of nonwhites in a settler state" (xix).

In the long chapter covering the period 1776-1910, Frederickson does not discuss federal Indian policy at all-let alone nineteenth-century Indian allotment policy in particularfocusing instead on important and illuminating comparisons between South Africa's treatment of indigenous South Africans and the United States' treatment of African Americans during that historical period. See "Liberty, Union, and White Supremacy, 1776-1910," in ibid., 136-98.

73 Ward Churchill, "Like Sand in the Wind: The Making of an American Indian Diaspora in the United States," in Since Predator Came, 177.

74 Janet A. McDonnell, The Dispossession of the American Indian, 1887-1934 (Bloomington and Indianapolis: Indiana University Press, 1991).

75 See Churchill, "Like Sand in the Wind," 195 n. 74.

76 As discussed earlier, McDonnell provides an illuminating discussion of the federal government's dubious and illegal experiment during the years $1917-20$ in using blood quantum to force "fee patents" on unconsenting Indian allottees under the pretense of "competency" determinations. See generally McDonnell, The Dispossession of the American Indian, 103-12. But of course Churchill does not purport to be discussing the 1917-20 "competency" policy of the Woodrow Wilson administration when he falsely asserts that "under provision of the [General Allotment Act of 1887]," Indians who were of less than half Indian blood "were summarily excluded from receiving allotments."

77 Early in her book, McDonnell provides a concise, two-paragraph summary of the contents of the General Allotment Act, which is worth excerpting at length:

"The Dawes Act authorized the president to allot reservation land to individual Indians and specified the amounts of land to be allotted: 160 acres to family heads; 80 acres to each single person over eighteen and each orphan under eighteen; and 40 acres to single persons under eighteen then living or born before the president ordered allotment. After the reservation had been opened, the government could purchase the surplus land and make it available to homesteaders.

"Under the act, the govern. ment would hold the title to the allotment in trust for twenty-five years to protect the allottee while he learned to use the land and support himself. The law embodied the concept of a trust relationship between the federal government and the Indians that had been evolving since the first days of this nation. Treaties signed in the eighteenth and nineteenth centuries had specified that the federal government would protect Indians in the use and occupancy of the lands they had reserved for themselves. The Dawes Act provided that after an individual 
selected a piece of tribal land, the government would issue a trust patent which restricted the Indian in the sale and use of that land. At the end of the trust period, when the Indian presumably could support himself and manage his own affairs, the government would replace the trust patent with a fee patent-a deed of unrestricted ownership-and relieve itself of its trust responsibility." (The Dispossession of the American Indian, 2)

McDonnell makes no mention here or elsewhere in her book of any "blood quantum" requirement for acquiring an allotment under the General Allotment Actcertainly an important facet to include in a summary of the legislation, if such requirement existed. But, for the simple reason, again, that the General Allotment Act in fact entailed no such eligibility requirement, McDonnell does not mention it.

78 The essays in Churchill's From a Native Son are not identical, of course, to the "versions" of those essays as they appear in Churchill's previously published books, for Churchill makes numerous silent alterations from one "version" to the next. For an example of one such "silent" alteration occurring across "versions" of Churchill's essays, see note 68 above, for another example, see note 92 .

79 Churchill, A Little Matter of Genocide.

80 For an excellent and engrossing study of the history of genocide as perpetrated against Indian tribes, see David E. Stannard, American Holocaust: Columbus and the Conquest of the New World (New York: Oxford University Press, 1992).

81 Churchill, "Nits Make Lice': The Extermination of North American Indians, 1607-1996," in A Little Matter of Genocide, 245-46.

82 In his endnote, Churchill states the following: "According to the
Act (ch. 119, 24 Stat. 362, 385, now codified at 18 U.S.C. 331 , seq.), to be considered 'Indian,' and thus eligible to receive a parcel of reservation land, one was required to document being of at least onehalf 'blood' of a specific and fed. erally recognized 'tribal group.' One could not be, say, one-quarter by descent of four different indigenous peoples through inter. marriage, and still be legally identified as native. Nor could one be adopted or naturalized as a citizen/ member of an indigenous nation. Needless to say, such criteria not only negated one of the most im. portant sovereign prerogatives of native peoples-definition of their own polities-it left far fewer eligible Indians than available plots of reserved land. Hence, the massive 'surplus' of indigenous property" ("Nits Make Lice," 285 n. 586).

At the end of the paragraph containing the sentence to which this endnote is appended, Churchill also provides another reference note citing two booksin their entirety - on the federal government's Indian allotment policy: Kirke Kickingbird (Churchill misspells the name as "Kirk Kicking Bird") and Karen Ducheneaux, One Hundred Million Acres (New York: Macmillan Publishing Co., 1973); and McDonnell, The Dispossession of the American Indian. See "Nits Make Lice," 285 n. 587. But as I have discussed earlier, nowhere in McDonnell's book is any mention made of Churchill's "blood quantum" eligibility "standard." The same is true of Kickingbird and Ducheneaux's important study of the nature and historical development of Indian land ownership in the United States. Despite Churchill's purported reliance on the Kickingbird and Ducheneaux volume, nowhere between the covers of that book is there any mention of a "blood quantum" eligibility requirement that Congress 
instituted, supposedly, when Congress passed the General Allotment Act in 1887. Like McDonnell in The Dispossession of the American Indian, authors Kickingbird and Ducheneaux provide a short, useful summary of the contents of the General Allotment Act: "The main provisions of the General Allotment Act were as follows: (1) a grant of 160 acres to each family head and of 80 acres to each other single person under eighteen $_{i}$ (2) a patent in fee (simple) to be issued to every allottee but to be held in trust by the government for twenty-five years, during which time the land could not be alienated or encumbered ${ }_{i}(3)$ a period of four years to be allowed the Indians in which they should make their selections after allotment should be applied to any tribe (failure of the Indians to do so would result in selections for them at the order of the secretary of the interior); and (4) citizenship to be conferred upon allottees and upon any other Indians who had abandoned their tribes and adopted the habits of civilized life. These provisions were applied to each reservation of major size in the West as the occasion arose" (One Hundred Million Acres, 20). That a "blood quantum" eligibility requirement is not set out in Kickingbird and Ducheneaux's summary of the General Allotment Act's contents is to be expected, of course, since the General Allotment Act in fact never included any such requirement.

83 Churchill, "Nits Make Lice," in A Little Matter of Genocide, 285 n. 586.

84 Ward Churchill, "Cold War Impacts on Native North America: The Political Economy of Radioactive Colonization," in A Little Matter of Genocide, 291-92.

85 Throughout A Little Matter of Genocide, Churchill employs a peculiar system of annotation entailing numbered endnotes as well as footnotes marked by a repeating cycle of symbols ("*," " $\nmid, "$ " $\neq, "$ etc.). These endnotes and footnotes contain basic citations, both authentic and counterfeit, as well as often laborious substantive discussions, both accurate and misleading. Moreover, the confusion created by this cumbersome system of reference notes is exacerbated by the fact that Churchill often repeats the same endnote citations and substantive discussions in footnote citations and substantive discussions, thus increasing his book's overall "bulk." In the book's introduction, Churchill attempts to excuse his admitted redundancy by opining that "since much of what follows has been said so little, it is worth saying some of it more than once" (11).

86 Churchill, "Cold War Impacts in Native North America," 292 n. In purporting to invoke supportive scholarship for his discussion of the General Allotment Act in this passage, Churchill cites Kickingbird and Ducheneaux (Churchill again misspells Kirke Kickingbird's name as "Kirk Kicking Bird"), One Hundred Million Acres, and Janet A. McDonnell (Churchill misspells McDonnell's last name as "McDowell"), The Dispossession of the American Indian. See ibid. But as discussed earlier, neither Kickingbird and Ducheneaux's book nor McDonnell's in reality provides any support at all for Churchill's false assertions about the General Allotment Act's "'blood quantum' formula."

In addition to continually misspelling authors' names in citations, citing entire books without specifying page numbers for specific information allegedly contained in those books, and providing citations to nonexistent or irrelevant statutes, Churchill also scrambles information from different sources, so as to render his citations useless in aiding readers who would like to investigate the 
veracity of his assertions. Thus, for example, in making dubious claims concerning the Santee Sioux (Dakota) "Uprising" of 1862-a tragic event in the history of America's betrayal of Indian tribes, and one in which I, as a member of the Santee Tribe, have a keen interest-Churchill purports to rely on a source, inter alia, that he cites in a footnote and in his bibliography as "William W. Folwell, History of the Santee Sioux (Lincoln: University of Nebraska Press, 1967)" (see Churchill, "Nits Make Lice,'" in A Little Matter of Genocide, 225-26 $n_{\text {; }}$ and Churchill, bibliography in A Little Matter of Genocide, 460). But no sucb source as this actually exists. Rather, this concocted "citation" of Churchill's appears to combine information from two different scholarly sources: William W. Folwell, A History of Minnesota, 4 vols. (St. Paul: Minnesota Historical Society, 1921-61 [original and reprinted editions]); and Roy W. Meyer, History of the Santee Sioux: United States Indian Policy on Trial (Lincoln: University of Nebraska Press, 1967). Deepening the confusion is the fact that among his two thousand or more bibliography entries in A Little Matter of Genocide (see 445-506), Churchill does not include any listing for Meyer at all, as author of the seminal History of the Santee Sioux or otherwise, but he does include two consecutive entries for Folwell-A History of Minnesota (which Folwell did author), and History of the Santee Sioux (which Folwell did not author) (see 460).

87 In both the "Nits Make Lice'" endnote and the "Cold War Impacts" footnote, Churchill posits a reference to the General Allotment Act as" "ch. 119, 24 Stat. 362, 385, now codified at 18 U.S.C. 331 et seq." But this reference is doubly erroneous, both in the citation it gives to United States Statutes at Large, and in the reference it gives to United States Code. As indicated earlier, the correct Statutes at Large citation for the General Allotment Act is ch. 119,24 Stat. 388, and the correct U.S. Code citation for the General Allotment Act, as amended, is 25 U.S. Code secs. $331-334,339,341,342,348,349$, 354,381 .

88 See ch. 26,24 Stat. 361,362 (1887).

89 See ch. 104, 24 Stat. 379,385 (1887).

90 See 18 U.S. Code sec. 331.

91 Actually, the number of times that Churchill's false assertions of fact have been republished is far greater, since Churchill tends to recycle numerous "versions" of his books' essays in a variety of periodicals. See "Works by Author, 1980-1996," in From a Native Son, 547-58. Thus, the damage that Churchill's propaganda has done to public perceptions of the legal and political concerns of Indian tribes extends far beyond the readership of his books alone.

92 It is interesting to note, too, that in the elaboration of this propaganda, Churchill over time has gradually phased out his reliance on Jaimes-Guerrero's "Federal Indian Identification Policy" as the origination point for this false General Allotment Act eligibility scheme. Thus, in reprinting "Nobody's Pet Poodle" for inclusion in his anthology From a Native Son, Churchill silently omits from the body of the essay reference to "the Juaneño/Yaqui scholar M. Annette Jaimes"-an attribution that had been present in the body of the Indians Are Us? "version" of "Nobody's Pet Poodle," and in the body of the essay "Perversions of Justice" in Struggle for the Landas the person who coined the phrase "a sort of statistical extermination" for describing the General Allotment Act "eligibility" scheme as laid out in "Federal 
Indian Identification Policy"; instead, in his From a Native Son "version" of "Nobody's Pet Poodle," Churchill relegates such "credit" exclusively to the essay's endnotes. See Churchill, "Nobody's Pet Poodle," in From a Native Son, 485,496 n. 2.

Likewise, in the detailed, twelve-pages-long listing of "Works by Author" at the end of From a Native Son, Churchill mentions neither The State of Native America (which in fact contains four essays authored or coauthored by Churchill) nor JaimesGuerrero-not even as editor of Churchill's own Fantasies of the Master Race (see From a Native Son, 549). And in the recently published A Little Matter of Genocide, Churchill gives no "credit" to Jaimes-Guerrero at all-not as a source of the General Allotment Act "eligibility" scheme, nor as editor of Fantasies of the Master Race, nor indeed as author or editor of any of the two thousand or more books and articles included in A Little Matter of Genocide's sixty-two pages of bibliography listings.

Clearly, whatever role JaimesGuerrero originally played in fabricating the tribal sovereigntybashing General Allotment Act "eligibility" scheme, Churchill today is taking sole "credit" for the deployment of this hoax.

93 Indian Arts and Crafts Act of 1990, Pub. L. No. 101-644, 104 Stat. 4662 (codified at 25 U.S.C.A. secs. 305d, 305e [West Supp., 1998]; as amendments to 25 U.S.C.A. sec. 305a [West Supp., 1998] and 18 U.S.C.A. secs. 1158 , 1159 [West Supp., 1998]; and as provisions set out as notes at 25 U.S.C.A. secs. 305, 305e [West Supp., 1998]).

94 House Report No. 101-400(I), at 3 (1990), reprinted in 1990 U.S. Code Cong. and Adm. News 6382.
95 Churchill, "Nobody's Pet Poodle," in Indians Are Us? 92.

96 Ibid.

97 Indian Arts and Crafts Act of 1990, Pub. L. No. 101-644, secs. 104(a), 105, 104 Stat. 4662, 4663, 4664 (codified at 18 U.S.C.A. sec. 1159(a) [West Supp., 1998], 25 U.S.C.A. sec. 305e(a) [West Supp., 1998]).

98 Ibid. (codified at 18 U.S.C.A. sec. 1159(c)(1) [West Supp., 1998], 25 U.S.C.A. sec. $305 \mathrm{e}$ (d)(1) [West Supp., 1998]).

99 House Report No. 101-400(I), at 6 (1990), reprinted in 1990 U.S. Code Cong. and Adm. News 6385 (stating that " $t]$ he new definition defines 'Indian' as any individual who is a member of an Indian tribe or any individual who, although not a member of an Indian tribe, is certified by that tribe to be of the tribe's lineage").

100 Protection of Indian Arts and Crafts Products, 25 C.F.R. sec. 309 (1998).

101 Under a section titled "How can an individual be certified as an Indian artisan?" the regulations provide the following:

(a) In order for an individual to be certified by an Indian tribe as a non-member Indian artisan for purposes of this part-

(1) The individual must be of Indian lineage of one or more members of such Indian tribe; and (2) The certification must be documented in writing by the governing body of an Indian tribe or by a certifying body delegated this function by the governing body of the Indian tribe (25 C.F.R. sec. 309.2 [1998]).

102 House Report No. $101-400$ (I), at 10 (1990), reprinted in 1990 U.S. Code Cong. and Adm. News 6389 (letter from Carol T. Crawford, Assistant Attorney General, U.S. 
Department of Justice, Office of Legislative Affairs, to Morris $\mathrm{K}$. Udall, Chairman, Committee on Interior and Insular Affairs, U.S. House of Representatives, August 15, 1989).

103 Jaimes, "Federal Indian Identification Policy," 131.

104 Jaimes-Guerrero's reference to offensive denunciations by "opponents" would appear to be an allusion to Churchill's efforts to vilify the Indian Arts and Crafts Act and citizens of Indian nations protected by the Act. Cf. Churchill, "Nobody's Pet Poodle," in Indians Are $U_{s}$ ? 90 (denouncing the act and likening members of Indian tribes to "stuffed poodles" and "Afghan hounds" that "also sport their pedigree papers" [emphasis in original]).

105 Jaimes, "Federal Indian Identification Policy," 131.

106 See Indian Arts and Crafts Act of 1990, Pub. L. No. 101-644, 104 Stat. 4662 (codified at 25 U.S.C.A. secs. 305d, 305e [West Supp., 1998] $]_{i}$ as amendments to 25 U.S.C.A. sec. 305a [West Supp., 1998] and 18 U.S.C.A. secs. 1158 , 1159 [West Supp., 1998]; and as provisions set out as notes at 25 U.S.C.A. secs. 305, 305e [West Supp., 1998]); House Report No. $101-400$ (I) and No. 101-400(II) (1990), reprinted in 1990 U.S. Code Cong and Adm. News 6382-6397; Protection of Indian Arts and Crafts Products, 25 C.F.R. sec. 309 (1998).

107 A similarly misleading and errorladen discussion of the Indian Arts and Crafts Act appears in a recent book, Scott B. Vickers, Native American Identities: From Stereotype to Arcbetype in Art and Literature (Albuquerque: University of New Mexico Press, 1998). Without supplying citations to any supporting authority (except for citing to Patricia Nelson
Limerick's The Legacy of Conquest for Vickers's out-of-context misrepresentation of Limerick's views), but with manifest admiration for Churchill for having "consistently opposed the racial bloodline cri. teria of the [Indian Arts and Crafts Act]" (164), Vickers discusses the Indian Arts and Crafts Act in the following terms:

"The law requires ... that Indian artists prove their affiliation with an Indian tribe, either by documenting their blood quantum ('Indian' artists must be 'one quarter or more Indian blood by birth') or by being registered as tribal members in the national registry of sanctioned tribes, begun in the 1880 s. The problems with this law are threefold.

"First, since the inception of the national Indian tribal registry, many Indians have refused or otherwise been denied inclusion on the official list, because their tribes were not recognized as such by government criteria. The progeny of these Indians today, whether or not they are fullblooded or even quarter-blooded Indians, have no way of officially proving their heritage, since their maternal or paternal lineages are not recorded. Second, as Patricia Nelson Limerick and others point out, the likelihood of any full-blooded Indians existing at all after circa the year 2080 is extremely unlikely ...

"Third, and most disturbing, is the fact that the law came into being because of jealousy among Indian artists themselves. ... Certainly, such divisiveness within the community of Indian artists itself speaks volumes about the extent to which racial criteria have had and continue to have a destabilizing and deracinating effect on Indian identities, confounding any meaningful discussion of 'Indianness,' a.concept that grows less and less definite, as perhaps it must, as time and this discussion go on. As historian 
Limerick has explained, 'Set the blood quantum at one-quarter, hold to it as a rigid definition of Indians ["Indianness" in Limerick's original], let intermarriage proceed as it has ["had" in Limerick's original] for centuries, and eventually Indians will be defined out of existence.' Surely, given such a possibility, the criterion of blood quantum must be reconsidered and eventually disavowed as a meaningful marker of Indian identity ..." (163-64, quoting Limerick, Legacy of Conquest, 338)

To borrow Vickers's phrase, the problems with Vickers's discussion of the Indian Arts and Crafts Act are manifold. First, the Indian Arts and Crafts Act does not provide that "Indian' artists must be 'one quarter or more Indian blood by birth,'" as Vickers erroneously claims. Second, whatever Vickers may mean by "the national Indian tribal registry," the Indian Arts and Crafts Act provides for complete deference to tribes themselves in determining who is "Indian" by virtue of being either a tribal member or an "Indian artisan" with tribal lineage; thus it is to the sovereign tribes themselves, not the federal government, that the "progeny" of those who "refused" to be on "the national tribal registry" - or anyone else, for that matter-must turn for sanction as tribal members or as persons of tribal lineage if they want to continue representing their commercial art products to the art-buying public as Indian-produced. Indeed, it is this strong deference to tribal self-determination that gives the Indian Arts and Crafts Act its commendable, tribal sovereigntystrengthening effect. Third, Vickers, like Churchill and Jaimes-Guerrero before him, thoroughly misrepresents the views of Limerick in attempting to lend credibility to his opinions in opposition to the Indian Arts and Crafts Act. Indeed, one wonders whether Vickers actually has consulted Limerick's book (which Vickers cites) at all, since the errors Vickers makes in "quoting" Limerick are identical to the errors that appear in the misrepresentations of Limerick in JaimesGuerrero's and Churchill's writings (which Vickers does not cite). Moreover, Vickers appears to do Churchill's and Jaimes-Guerrero's misrepresentations of Limerick one better by silently combining those misrepresentations with Churchill's additional misrepresentation of the views of Russell Thornton. Thus, Vickers asserts, without any supporting citation, that "Limerick and others point out" that "the likelihood of any full-blooded Indians existing at all after circa the year 2080 is extremely unlikely. ..." In reality, of course, Limerick does not "point out" any such thing. Fourth, Vickers's depiction of the Indian Arts and Crafts Act as having "[come] into being because of jealousy among Indian artists themselves" and as causing "divisiveness within the community of Indian artists" merely obscures the true purpose and import of the act as an anti-fraud and consumer protection device that is detested, predictably, by certain individuals who emphatically are outside "the community of Indian artists"i.e., by those non-Indians who would continue to perpetrate the same kind of lucrative fraud that Indian tribes had prevailed on Congress to curb by means of this legislation. The fact that Vickers's distortions of the Indian Arts and Crafts Act blend so seamlessly with Churchill's and JaimesGuerrero's similar efforts to confuse the public about this act "speaks volumes" not about any flaw in the act's crucial deference to Indian tribes but about the single-mindedness of those intent on undermining this powerful, proIndian legislation through propaganda and deception. The clear 
unity-of-purpose in these assorted writings also "speaks volumes" about the alarming ease with which patently false propaganda in derogation of Indian tribes finds its way into print during these final years of twentieth-century America.

108 See LaVelle, "Review Essay," 117-18.

109 Felix Cohen, "Author's Acknowledgments," in Felix S. Coben's Hand- book of Federal Indian Law, 1942 ed., xxxii.

110 Churchill, introduction to A Little Matter of Genocide, 10 (citing Noam Chomsky, Class Warfare: Interviews with David Barsamian [Monroe, Maine: Common Courage Press, 1996]).

111 Churchill, introduction to Struggle for the Land, 10. 